\title{
Demography of the Brazil nut tree (Bertholletia excelsa) in the Bolivian Amazon: impact of seed extraction on recruitment and population dynamics
}

\author{
PIETER A. ZUIDEMA* $\star^{1}$ and RENÉ G. A. BOOT*† \\ *Programa Manejo de Bosques de la Amazonía Boliviana (PROMAB), Casilla 107, \\ Riberalta, Beni, Bolivia \\ $\dagger$ Department of Plant Ecology, Utrecht University, PO Box 80084, 3508 TB Utrecht, The \\ Netherlands \\ (Accepted 22nd April 2001)
}

\begin{abstract}
A demographic study was carried out on Bertholletia excelsa, the Brazil nut tree, in two primary forest sites in Northern Bolivia where Brazil nuts have been harvested for several decades. In spite of the large proportion (93\%) of seeds that are harvested, reasonable densities of recently emerged seedlings were found. Seeds of Bertholletia are contained in woody fruits that are primarily opened by agoutis. Most fruits are left untouched on the forest floor for 1-2 y before they are opened, possibly due to high energetic costs of fruit opening just after fruit fall. However, the proportion of viable seeds is strongly reduced in older fruits.

Growth in diameter at breast height $(\mathrm{dbh})$ was low for pole-sized trees $(<15$ $\mathrm{cm} \mathrm{dbh})$ and adult trees $(>100 \mathrm{~cm} \mathrm{dbh})$ and peaked for intermediate-sized trees $(30-60 \mathrm{~cm})$. These trees often attained a growth rate of $>1.5 \mathrm{~cm} \mathrm{y}^{-1}$, which is high compared with other non-pioneer tropical trees. This, and the strong growth response to increased light availability found for seedlings and saplings, suggest that Bertholletia excelsa can be classified as a gap-dependent species. Matrix population models were constructed for both study populations. Population growth rates $(\lambda)$ were close to one, and were most sensitive to persistence in one size category. Age estimates revealed that age at first reproduction (at $\mathrm{dbh}>60 \mathrm{~cm}$ ) amounts to over $120 \mathrm{y}$, and age in the last category $(\mathrm{dbh}>160 \mathrm{~cm})$ to almost $300 \mathrm{y}$. Given the continuous rejuvenation of the population, the stable population size, the high age at maturity and the long reproductive period, it is concluded that current levels of Brazil nut extraction may be sustained at least for several decades and perhaps for even longer periods.
\end{abstract}

KEY WORDS: Bertholletia excelsa, Bolivia, Brazil nuts, demography, matrix population model, non-timber forest product, seed extraction, sustainable use, tropical forest

\footnotetext{
1 Address for correspondence: Pieter Zuidema, Plant Production Systems Group, Wageningen University,
} Haarweg 333, 6709 RZ Wageningen, The Netherlands. Email: Pieter.Zuidema@pp.dpw.wau.nl 


\section{INTRODUGTION}

The Brazil nut has received ample attention in the last decade as an example of an economically important non-timber forest product (NTFP) with high potential for sustainable use (Clay 1997, Fearnside 1989, Prance 1990, Richards 1993). The nut, produced by the emergent Amazonian tree Bertholletia excelsa Humb. \& Bonpl., is predominantly collected from primary rain forest sites and its extraction has little impact on species composition and forest structure. Collection and processing of Brazil nuts is of major importance in local and regional economies in the Amazon regions of Bolivia, Brazil and Peru (Broekhoven 1996, Dominguez 1994, LaFleur 1992, Mori 1992), generating income for thousands of families (Clay 1997, Stoian 2000). Although recent socio-economic studies suggest that the potential of Brazil nuts as a major pillar for sustainable forest management and regional development may not be as large as expected (Assies 1997, Bojanic Helbringen 2001, Homma 1996, Mori 1992), it remains an important example of how a 'minor' non-timber forest product may have a major influence on a regional economy without large-scale forest alteration. Furthermore, exploitation of the Brazil nut tree in natural forest stands may be an adequate vehicle for conservation of its forest habitat, as efforts to grow Bertholletia excelsa in plantations have not been very successful, probably due to the lack of efficient pollinators (Mori \& Prance 1990), the risk of inbreeding and the economics of establishing plantations. Certification of forests from which Brazil nuts are extracted may also serve the purpose of forest conservation (CFV 2000).

Despite the economic importance of the Brazil nut, its long extraction history (Mori \& Prance 1990) and its example role for sustainable forest management, very little is known about the impact of extraction on the demography of the species and on the future availability of nuts. So far, studies on Bertholletia excelsa have mainly focused on aspects of its cultivation: germination (Kainer $e$ t al. 1999, Müller 1981), seedling growth (Kainer et al. 1998, Poorter 1999, Zuidema et al. 1999), enrichment planting (Kainer et al. 1998, Oliveira 2000, Peña-Claros et al. in press) and establishment of plantations (Mori \& Prance 1990 and references therein, Müller 1981). Studies in natural populations have concentrated on population structures (Peres \& Baider 1997, Salomao 1991, Viana et al. 1998), population genetics (Buckley et al. 1988, O’Malley et al. 1988), pollination mechanisms (Müller et al. 1980, Nelson et al. 1985) and dispersal ecology (Peres \& Baider 1997, Peres et al. 1997, Tabarelli \& Mantovani 1996, Terborgh et al. 1993). In spite of the considerable research attention paid to Bertholletia in the biological literature, a quantitative analysis of the entire life cycle of the species is still lacking. Such analysis is crucial to determine the impact of large scale and intensive seed removal from natural populations on the maintenance of populations and the future availability of Brazil nuts.

In this paper we present results of a study on the demography of Bertholletia excelsa in two Bolivian primary forest sites where Brazil nuts have been collected 
for several decades. The first goal of this study is to determine whether recruitment of new seedlings still occurs in exploited populations. Extraction of Brazil nuts from natural populations interferes with the complex dispersal strategy of Bertholletia excelsa. Seed dispersal in this species strongly depends on caviomorph rodents (agoutis, Dasyprocta spp.) that are able to gnaw open the woody fruits and subsequently disperse part of the seeds. In forests where Brazil nuts are collected, a large number of seeds is taken away. This is likely to alter seed handling of the agoutis, as they tend to consume (i.e. destroy) more and scatterhoard less seeds when food availability is low (Bouwman \& van Dijk 1999, Forget 1996). The proportion of seeds extracted by Brazil-nut collectors and the proportion of the remaining fruits that is opened by agoutis, was determined for the study area. As the woody fruits can remain intact on the forest floor for some time, seed condition will be related to time since fruit fall. Furthermore, the spatial distribution of fruits and seedlings was determined and the consequences of seed dispersal, seed predation and germination on this distribution were evaluated.

The second goal was to analyse population dynamics of the species under primary forest conditions, with the final purpose to determine the consequences of seed removal for population dynamics. To this end, we investigated size-dependent patterns of survival, growth and reproduction and assessed the regeneration strategy of the species by relating growth to light availability. The effect of climatic variation on demographic rates was also investigated as one of the two measurement years coincided with a particularly dry (El Niño) year. Dry years occur regularly in northern Bolivia and may be common throughout the distribution area of Bertholletia excelsa as it typically occurs in areas with 2-7 dry months (<60 mm precipitation, Müller 1981). Population matrix models were constructed to obtain insight into the importance of different life stages and processes for population maintenance and growth. Furthermore, we derived age estimates for different size categories. Such estimates can be used to determine at what time scale Brazil nut extraction may influence future availability of the resource. Finally, the information on recruitment and population dynamics was used to assess the consequences of nut extraction for population maintenance and sustained seed production.

\section{STUDY SPEGIES}

Bertholletia excelsa (Lecythidaceae) is a large emergent neotropical forest tree that may attain a total height of up to $50 \mathrm{~m}$ and a diameter at breast height (dbh) of up to $300 \mathrm{~cm}$ (exceptionally 400-500 cm, Salomao 1991). The species is distributed throughout Amazonian forests in non-flooded (terra firme) forests (Mori \& Prance 1990). Peres \& Baider (1997) reported clumped distribution of Bertholletia at the landscape level, but random distribution of individuals within stands. In the northern Bolivian Amazon region, the predominant density of adult trees is $1-5 \mathrm{ha}^{-1}$ (DHV 1993). Due to its large adult stature, Bertholletia 
often accounts for a large proportion of total basal area (DHV 1993, Salomao 1991).

Bertholletia has a complex dispersal ecology that almost completely depends on the scatterhoarding activity of agoutis (Peres \& Baider 1997). Seeds of the species are contained in large capsular woody fruits - pyxidia - with a diameter of over $10 \mathrm{~cm}$. Primary dispersal is by gravity (barochoric): fruits drop to the forest floor, but are not damaged by the impact of the fall and remain closed. As the fruits do not possess an opening sufficiently large for the big seeds (c. $20 \times 50 \mathrm{~mm}$ ) to leave the fruit without assistance, seeds can only be released by active opening. This is done predominantly by diurnal agoutis which gnaw open the thick and tough woody pericarp of the fruit (Peres \& Baider 1997). Agoutis typically eat some of the seeds after opening the fruit, and scatterhoard the remaining seeds for later consumption, usually at a distance of $<10 \mathrm{~m}$ (Bouwman \& van Dijk 1999, Peres \& Baider 1997). Cached seeds are predated upon by agoutis and other species including rodents (Peres \& Baider 1997), by tracking the scent of the seeds (Murie 1977). Those seeds that are not consumed within the germination period of Bertholletia (12-18 mo, Müller 1981) may germinate. Germination success seems to be dependent on moist storage conditions (Kainer et al. 1999), and seeds may remains viable for several years (Watson 1901).

On rare occasions seeds may also be found germinating within an intact fruit on the forest floor (Peres \& Baider 1997, P. A. Zuidema, pers. obs.). Clumps of seedlings surrounded by the remains of a fruit have also been found (P. A. Zuidema, pers. obs.), probably indicating that seeds have germinated after the woody pericarp has completely disintegrated.

Brazil-nut collection is carried out in the wet season during or after the main peak in fruiting. During collection, fruits are sought below the tree crown, taken to a central location below or just outside the tree crown and opened with a machete. The seeds are then taken out of the fruits and transported in bags to a nearby house or settlement for subsequent transport to processing plants.

\section{METHODS}

\section{Study sites}

This study was carried out in two primary moist tropical forest sites in the northern Bolivian Amazon which are about $140 \mathrm{~km}$ apart. The first site, El Tigre Forest Reserve (Beni Department, 10 $0^{\circ} 59^{\prime} \mathrm{S}, 65^{\circ} 43^{\prime} \mathrm{W}$ ) is a 830-ha research site of the Programa Manejo de Bosques de la Amazonia Boliviana located $50 \mathrm{~km}$ from the town of Riberalta. Annual precipitation in Riberalta amounts to about $1703 \mathrm{~mm}$ (average over 1948-1998) with a pronounced dry season from May to September $\left(<100 \mathrm{~mm} \mathrm{mo}^{-1}\right)$.

The second research site is located close to the community El Sena (Pando Department, $11^{\circ} 30^{\prime} \mathrm{S}, 67^{\circ} 15^{\prime} \mathrm{W}$ ), in a forest area with similar forest structure 
and species composition. The abundance of adult Bertholletia trees is comparable between the sites. No precipitation data are available for El Sena, but total annual precipitation is comparable between sites (Beekma et al. 1996), although seasons are slightly shifted to later dates in El Sena. Related to this, the Bertholletia fruiting season also starts later: in El Sena fruits fall from November till February (peaking in January) compared to October till January (peak in December) in El Tigre.

In both sites Brazil nuts were collected during the study period. Nut extraction has been carried out for several decades in both areas, as El Tigre is in the vicinity of the town where most Brazil nuts are processed and El Sena has been an important settlement for a long period (Fifer 1970). Agoutis are commonly hunted in El Sena for their meat; in El Tigre hunting has been forbidden since 1994, but has probably not ceased altogether.

During the second measurement year rainfall in Riberalta was strongly reduced: during the wet season (Dec '97-Mar '98) precipitation amounted to $874 \mathrm{~mm}$ compared to an average value of $1037 \mathrm{~mm}(\mathrm{SD}=234 \mathrm{~mm}$ for '48-'98 data), during the subsequent dry season (May '98 - Sep '98) this was $94 \mathrm{~mm}$ compared to an average of $203(\mathrm{SD}=73 \mathrm{~mm})$. The subsequent occurrence of two drier-than-normal seasons caused the 12-mo moving average precipitation to drop below $100 \mathrm{~mm} \mathrm{mo}^{-1}$ which is considerably lower than average $(143 \mathrm{~mm}$ $\mathrm{mo}^{-1}$ ). Moving average values below $100 \mathrm{~mm} \mathrm{mo}^{-1}$ were also observed in other years with very low rainfall in both wet and dry season (1956, '63, '69, '83 and '85), occurring at a frequency of $0.12(=6 / 50)$ during the period 1948-1998. Three out of these six considerably drier years coincided with El Niño Southern Oscillation episodes (ENSO), but significant anomalies in monthly precipitation during ENSO episodes were not found (results not shown; cf. Ropelewski \& Halpert 1996).

\section{Study design}

In each of the study sites measurements on Bertholletia individuals of all sizes were carried out in a permanent plot. In El Tigre a 12-ha $(400-\mathrm{m} \times 300-\mathrm{m})$ plot was established to search for and tag all Bertholletia individuals $>5 \mathrm{~cm}$ dbh (diameter at breast height). Individuals $<5 \mathrm{~cm}$ dbh and seedlings were searched for and tagged in six randomly chosen $25-\mathrm{m} \times 25-\mathrm{m}$ subplots per ha (total searched area equalled $4.5 \mathrm{ha}$ ). In two of these subplots per ha, seedlings of all sizes (with minimally one fully expanded leaf) were searched for at initial measurement, and these plots were used to quantify seedling recruitment after 1 and $2 \mathrm{y}$. In the remaining four subplots per ha, larger seedlings $(>50 \mathrm{~cm}$ height) and pole-sized trees $(<5 \mathrm{~cm} \mathrm{dbh})$ were searched for during the initial field evaluation. In El Sena a similar method was used, but in a 6-ha plot and using a $20-\mathrm{m} \times 20-\mathrm{m}$ grid. At this site, seedlings of all sizes and pole-sized trees were searched for and tagged in six randomly chosen subplots per ha (total area: $1.4 \mathrm{ha}$ ). In both sites, seedlings and pole-sized trees encountered outside 
the selected subplots or just outside the plots were also included to increase sample size.

Narrow trails used by Brazil-nut collectors dissected the study plots in both sites, but these do not significantly influence the prevailing understorey light regime. Brazil-nut collection in the study area was carried out without removing the understorey vegetation.

Additional Bertholletia trees in primary forest outside the study plots were searched for to increase sample size. A total of 273 trees of $>4 \mathrm{~cm}$ dbh (El Tigre: $\mathrm{n}=135$; El Sena: $\mathrm{n}=138$ ) were encountered along forest trails within c. $2 \mathrm{~km}$ distance from the study plots.

\section{Field measurements}

Bertholletia individuals included in the study were measured annually. Trees $>1 \mathrm{~cm}$ dbh were generally measured at the end of the dry season (in Oct-Nov) during 1996-98. An additional measurement was conducted for trees outside the study plots in Dec 1999 (El Sena) and Jan 2000 (El Tigre) to obtain growth data over $3 \mathrm{y}$. In El Sena, some of the individuals $>1 \mathrm{~cm}$ dbh included in the study had been marked and measured in 1992, which made it possible to verify the dbh growth rates obtained over the 2-y study period. Individuals $<1 \mathrm{~cm}$ dbh were measured in Feb-Mar during 1997-99.

For individuals $>1 \mathrm{~cm}$ dbh, reproductive status and dbh (at $1.3 \mathrm{~m}$ height; to nearest $\mathrm{mm}$, using pi-graduated tape) were recorded at each field evaluation. At initial measurement, the location of the diameter tape was marked with paint on at least three positions around the tree bole to fix the position of $\mathrm{dbh}$ measurements. The number of fruits opened by Brazil-nut collectors was counted for all reproductive trees within the plots and a random selection of individuals outside the plots (El Tigre: $\mathrm{n}=33$; El Sena: $\mathrm{n}=41$ ). In El Tigre, use was made of data on fruit production of 42 trees that were studied simultaneously with the present study (Leigue Gómez \& Boot, in press). Total height and height up to first branch of each individual $>1 \mathrm{~cm}$ dbh were estimated once during the study period.

For individuals $<1 \mathrm{~cm} \mathrm{dbh}$, plant height (to nearest $\mathrm{cm}$, following the stem) and number of green leaves (marking the newest leaf at every branch to determine leaf production) were recorded annually.

All measured individuals were assigned a score of the modified Dawkins illumination index (Clark \& Clark 1992) to characterize light climate. The scores were 1 (no direct lateral or overhead light), 2L (little direct lateral light, no overhead light), 2M (some direct lateral light, no overhead light), 2H (substantial direct lateral light, no overhead light), 3 (some overhead direct light), 4 (full overhead direct light; in canopy) and 5 (full overhead and lateral direct light; emergent). All studied individuals inside the plots were mapped to the nearest metre.

The density of fruits which were not removed by Brazil-nut collectors was assessed in the recruitment subplots in Mar-Apr 1998 and Feb-Mar 1999. The 
following parameters were recorded: location to the nearest metre, whether opened by agoutis and the time since the fruit fell to the forest floor. The latter was assessed by experienced Brazil-nut collectors, based on: (1) whether the fruit still possessed an outer shell around the woody pericarp; and (2) the toughness of the woody pericarp. The outer shell of the fruit disintegrates within $1 \mathrm{y}$; the woody pericarp is known to disintegrate in $3 \mathrm{y}$. A 1-y-old fruit is therefore notably harder than a 2-y-old fruit.

To determine the viability of seeds in fruits of different age, 50 fruits aged 0, 1 and 2 y were selected outside the study plots in both sites in March 1999. The total number of seeds per fruit was counted and each seed was opened to verify its quality.

\section{Data analysis}

As the study was conducted during years with differing precipitation (normal and dry years), the measured demographic rates (survival, growth and fruit production) were first tested for differences between years. This was carried out for each site separately. In the case of no difference, data of the two measurement years were pooled for further analyses. Subsequently, differences between sites were investigated, mostly in combination with the analysis of size-dependent patterns in the demographic parameter under consideration. This was carried out using linear, non-linear or logistic regression models. In addition, the influence of light level on demographic rates was assessed using the Dawkins illumination scores.

Analysis of growth in dbh was confined to those individuals for which no measurement problems were recorded (infestation of the bark by termites, a peeling bark and local irregularities in the tree bole). The removal of individuals with measurement problems reduced the number of individuals for dbh growth analysis by 15 and 17\% for El Tigre and El Sena respectively. Annual $\mathrm{dbh}$ growth was determined as the slope of a linear regression of dbh against time (over 2-3 y; 6 y for some trees in El Sena).

Tree diameter growth is typically non-linearly related to initial diameter, with low values for both small and large-sized individuals and high growth rates at intermediate sizes. To describe this pattern, a growth equation (Zeide 1993) was fitted through the dbh growth data, using a non-linear regression procedure with a least-squares loss function. The used equation (Hossfeld IV) is of the form:

$$
\Delta \mathrm{dbh}=\frac{b \times c \times \mathrm{dbh}^{(c-1)}}{\left[b+\left(\mathrm{dbh}^{c} / a\right)\right]^{2}}
$$

where $\Delta \mathrm{dbh}$ is the annual dbh growth rate $\left(\mathrm{cm} \mathrm{y}^{-1}\right)$ and $a, b$ and $c$ are fitted parameters.

Spatial distribution of fruits and seedlings relative to adult trees was assessed following the methodology of Hamill \& Wright (1986). This analysis was performed only for the study site El Tigre due to the irregular form of the 
El Sena plot. Using this method it is possible to determine whether fruits or seedlings have a clumped, random or over-dispersed spatial distribution relative to adult trees. The method uses a null distribution which assumes a random distribution of seedlings relative to adult trees, i.e. that each location in a plot is equally likely to contain a seedling (formulae in Hamill \& Wright 1986). By comparing the relative dispersion of fruits left by Brazil-nut collectors, fruits opened by agoutis, newly emerged seedlings and older small seedlings, insight is gained in the spatial pattern of the processes of seed dispersal, germination and early seedling survival.

\section{Transition matrix construction}

The study populations were divided into 17 size categories: the four smallest based on plant height and the remaining on dbh (Table 1). Categorization was based on biological criteria that maximize differences in demographic rates among categories. For example, the first size category was chosen such that it included all newly emerged seedlings. Similarly, the first reproductive category was established so as to maximize the contrast in fecundity between categories. Furthermore, limits for the first seven categories were chosen such that the height range of each successive category was doubled (Table 1).

Stage-based population matrix models (Caswell 1989, Lefkovitch 1965) were used to project the size and structure of populations in time. These models have a convenient standardized form, have relatively low data requirements for model parameterization and are a useful tool to examine consequences of demographic disturbances that may result from extraction of plant parts (Boot \& Gullison 1995). Matrix models use the equation $\mathbf{n}(t+1)=\mathbf{A} \times \mathbf{n}(t)$, where $\mathbf{n}(t)$ and $\mathbf{n}(t+1)$ are column vectors that contain the population structure at time $t$ and $t+1$, and $\mathbf{A}$ is a square matrix containing transition probabilities among categories during one year. In this equation, the population structure at time $t+1$ is obtained by multiplying the structure at time $t$ with the transition matrix that contains information on the dynamics of the population. When repeating this multiplication many times, the population structure (in relative terms) and population growth rate become stable. In that situation, the rate at which the population grows (the asymptotic population growth rate) is equal to the dominant eigenvalue $(\lambda)$ of matrix $\mathbf{A}$, which is an inherent characteristic of the transition matrix. The stable population structure is also equal to a characteristic of matrix A: the right eigenvector. For further theoretical documentation on matrix models, see Caswell (1989).

Elements $a_{i j}$ of transition matrix $\mathbf{A}$ can be grouped according to their position in the matrix: growth elements $(G)$ represent an individual's probability to grow from one category to the next (they are positioned in the subdiagonal of the matrix); stasis elements $(P)$ represent the probability of remaining in the same category (elements in the diagonal) and fecundity elements $(F)$ represent the number of offspring produced by an individual in a certain category (elements in the upper row, except for the top-left element). 


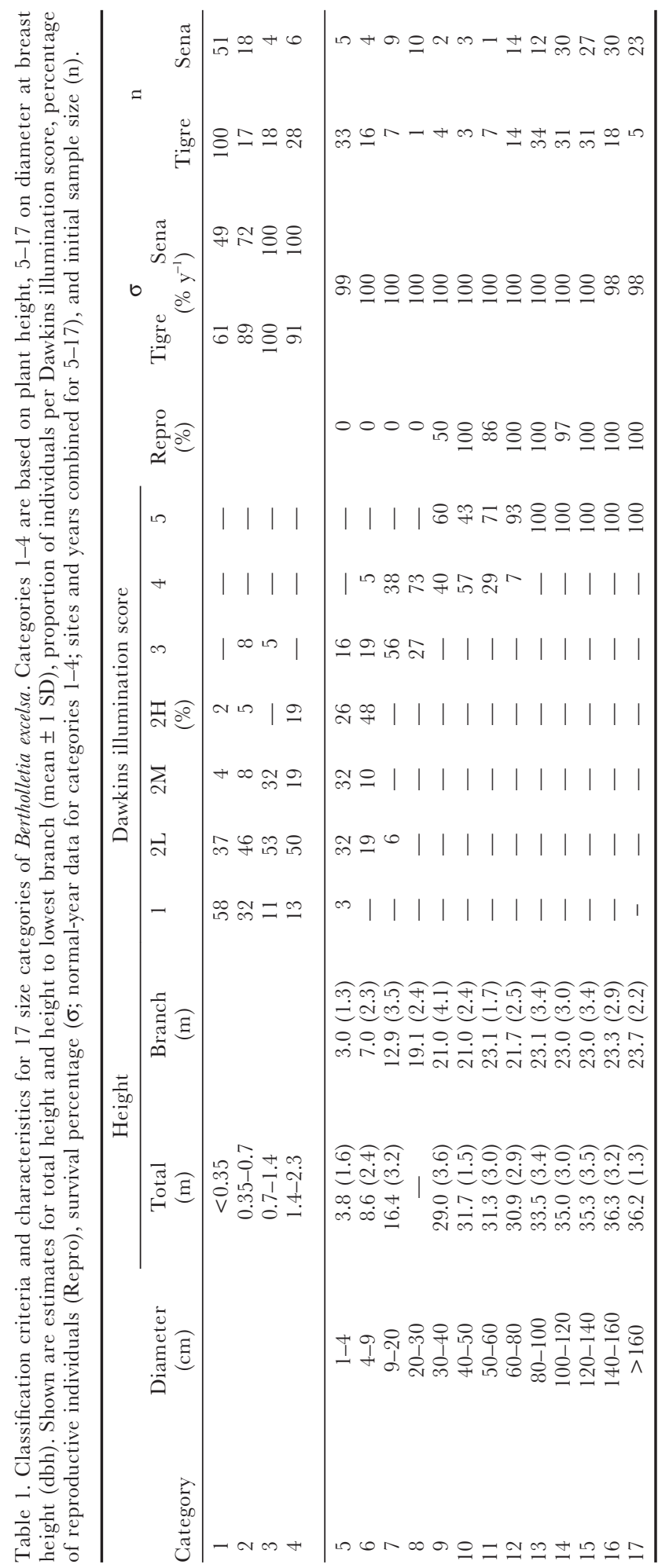


Four transition matrices were constructed: one for each combination of study site and year-type. Matrix elements were parameterized using demographic (or vital) rates: survival, growth and reproductive output (Caswell 1989). The value of the growth element $(G)$ of category $i$ was calculated as $G_{i}=\sigma_{i} \times g_{i} \times$ $c_{i}^{-1}$, where $\sigma_{i}$ is the survival probability in that category, $g_{i}$ the growth rate $(\mathrm{cm}$ $\left.\mathrm{y}^{-1}\right)$ and $c_{i}$ the category width $(\mathrm{cm})$. Stasis elements $(P)$ were then determined as $P_{i}=\mathrm{I}_{i}-G_{i}$. Fecundity $(F)$ elements were calculated as $\mathrm{F}_{i}=\sigma_{i} \times \operatorname{Pr}\{f\}_{i} \times f_{i}$, where $\operatorname{Pr}\{f\}_{i}$ is the probability that an individual in category $i$ is reproductive and $f_{i}$ the number of offspring produced by a reproductive individual in category $i$. The value of $f_{i}$ was determined as the category-specific fruit production, multiplied by the number of seedlings that emerged per fruit produced during the previous year. A time-lag of 1 y between fruit production and appearance of new seedlings is too short for most seedlings given that the majority of fruits is not opened directly after fruit fall (see Results), and the reported time to germination is 12-18 mo (Müller 1981). However, insufficient data on fruit production were available from preceding years to use a longer time-lag. As fruit production at the population level remains rather constant over years (Leigue Gómez \& Boot, in press), the influence of this calculation on model output is probably small. The number of newly emerged seedlings was counted in subplots. Total fruit production for the study plots was determined by counting all fruits harvested by Brazil-nut collectors and adding the number of fruits that remained after harvest which was based on counts in subplots.

\section{Population matrix analyses}

Both time-invariant and time-varying matrix models were applied to simulate population dynamics of Bertholletia in the two study sites. For the timeinvariant models - standard matrix models that assume demography to be constant in time - population growth rates $(\lambda)$ were calculated. Furthermore, elasticity analysis (de Kroon et al. 1986) was carried out to determine the sensitivity of the asymptotic population growth rate to changes in different elements in the transition matrix. Elasticity analysis is a frequently used type of sensitivity analysis for matrix models, which considers the proportional change in population growth rate $(\lambda)$ resulting from a proportional change in one of the matrix elements.

Age estimates were derived for each size category, using a set of equations that has been developed for matrix models in which individuals are grouped by size (Cochran \& Ellner 1992). Mean age at entering a category $(\tau)$ and mean age within a category ('age of residence'; $S$ ) were calculated. In addition, age estimates were obtained using growth simulations (following Lieberman \& Lieberman 1985).

Time-varying models were applied to describe long-term population dynamics for sequences of normal and dry years. As dry years occur randomly in time, a 'time-homogeneous stochastic model' was applied (sensu Caswell 1989). This model chooses one of the two year-types randomly at each time 
step for a long period of time. Subsequently, the overall average growth rate over this long period is calculated. Although year-types are chosen at random in the model, the probabilities of occurrence of each of the year-types is fixed. At each time step, the instantaneous population growth is calculated as (Silva et al. 1991):

$$
\log \lambda(t)=\log N(t+1)-\log N(\mathrm{t})
$$

where $N$ is the population size and $\log \lambda(t)$ is the growth rate. These instantaneous estimates can then be averaged over a long time interval (usually $T=$ 3000 y; Silva et al. 1991) using:

$$
\overline{\log \lambda_{s}}=\frac{1}{T-1} \sum_{t=1}^{T-1} \log \lambda(t)
$$

In stochastic matrix models, autocorrelation among year-types may play an important role, i.e. it makes a difference if dry years occur in sequence or well-spread in time. Autocorrelation ( $\rho$ ) is defined as $\rho=1-p-q$ (Silva et al. 1991), where $q$ is the probability that a normal year is followed by a dry year and $p$ is the probability of the reverse. Positive autocorrelation values $(0<\rho$ $<1)$ imply that years of the same type tend to appear in a row, and negative values $(-1<\rho<0)$ that they tend to alternate. The frequency of dry years $(\pi)$ is related to the degree of autocorrelation as $\pi=q /(1-\rho)$. The dry-year frequency used in the stochastic models was obtained from the meteorological records $(\pi=0.12)$, without allowing the occurrence of two consecutive dry years $(p=1$; thus $\rho=-q=0.136)$.

\section{RESULTS}

Size distribution, tree allometry and reproductive status

Bertholletia population structures in the study sites showed a declining abundance from small seedlings to large adult trees (Figure 1), with a slightly higher abundance of large trees (60-160 $\mathrm{cm}$ dbh; categories 12-16) compared to trees of $10-60 \mathrm{~cm}$ dbh (7-11). This was more clearly observed in the larger sample of trees measured outside the plots (inset in Figure 1). In El Sena no individuals of $1-4 \mathrm{~cm}$ dbh were found inside the subplots that were searched, although some individuals of that size were found and measured outside these subplots. The largest individual was found in El Sena measuring $267 \mathrm{~cm} \mathrm{dbh}$; in El Tigre the maximum dbh was $190 \mathrm{~cm}$. The 'hump' of large reproductive individuals in El Sena was located at higher dbh values: the average dbh for reproductive individuals there was $126.9(\mathrm{SD}=38.2)$ compared to $107.5 \mathrm{~cm}$ $(\mathrm{SD}=30.8)$ in El Tigre ( $\mathrm{t}$-test: $\left.\mathrm{t}_{263}=-4.66 ; \mathrm{P}<0.001\right)$.

Tree height steeply increased in individuals up to $40 \mathrm{~cm} \mathrm{dbh}$, after which height increment per unit dbh increment levelled off (Table 1; cf. Salomao 1991). Reproductive trees were 26-42 m tall (total height). Height up to first branch of adult trees ranged from 15 to $30 \mathrm{~m}$, the latter not being different between sites ( $\mathrm{t}$-test: $\mathrm{t}_{280}=-1.21 ; \mathrm{P}>0.05$; overall mean $\left.=22.6 \mathrm{~m}\right)$. Height to 


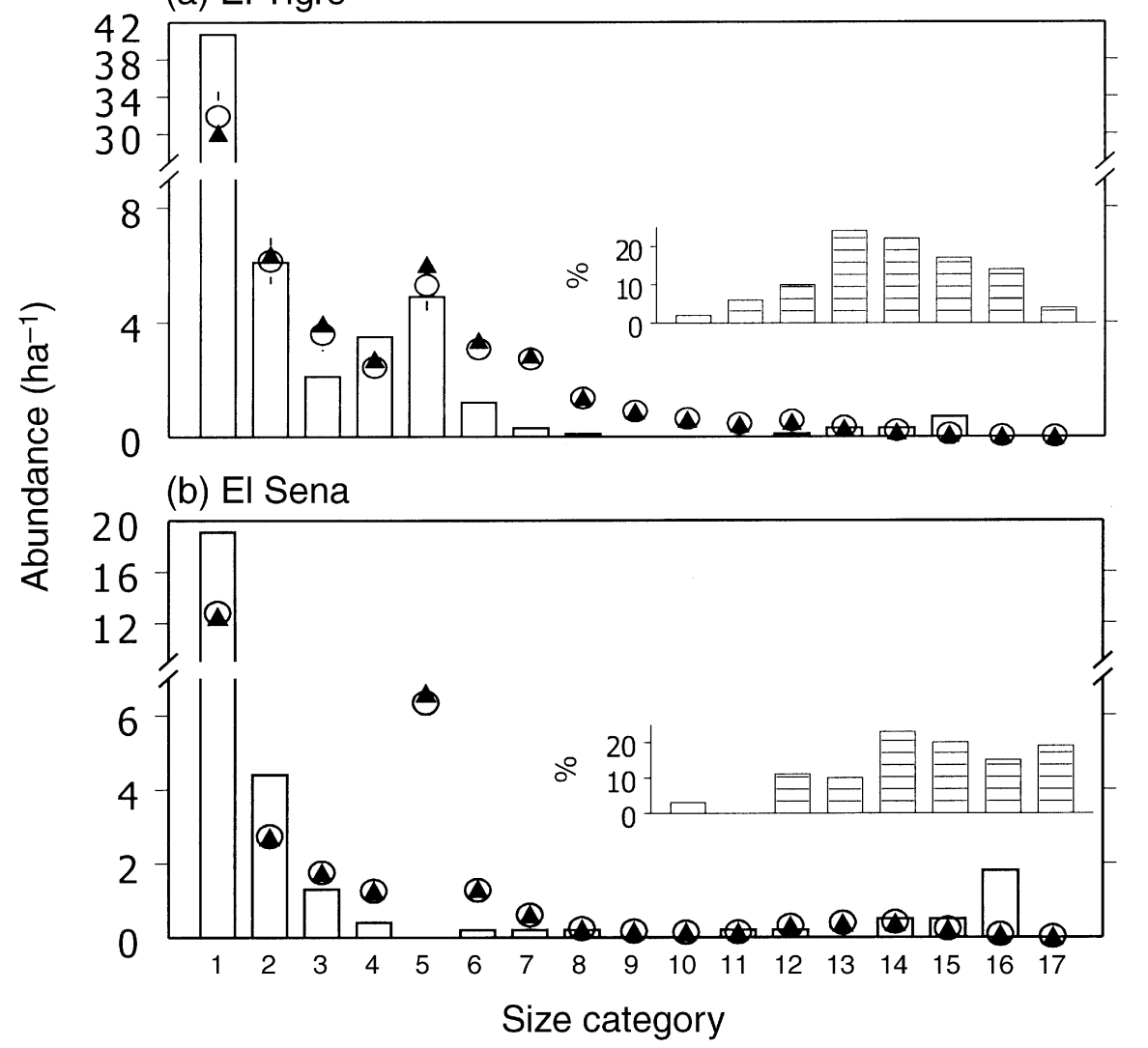

Figure 1. Population structures of Bertholletia excelsa in two sites in the Bolivian Amazon where Brazil nuts are extracted: El Tigre (a) and El Sena (b). Shown are observed population structure from study plot data (bars) and stable stage structures resulting from a time-invariant matrix model for a normal year $(\boldsymbol{\Delta}$; the right eigenvector of matrix $\mathbf{N})$ and a stochastic time-varying model for normal and dry years $(\bigcirc$; the average population structure resulting from the stochastic model, $\pm 1 \mathrm{SD})$. The hatched bars in the inset denote the proportion of individuals measured outside the study plots in categories $10-17(\mathrm{n}=127$ for El Tigre and 120 for El Sena).

first branch was linearly related to the ln-transformed dbh (height $[\mathrm{m}]=-0.68$ $\left.+5.0 \times \ln (\mathrm{dbh}[\mathrm{cm}]), \mathrm{r}^{2}=0.80, \mathrm{n}=341, \mathrm{P}<0.001\right)$, also indicating the larger height increment per $\mathrm{cm}$ of dbh increment for small individuals. This allometric relation was not different between sites (no effect of adding site to linear regression).

Reproductive status was strongly related to tree size (Figure 2): 98\% of the individuals with $\mathrm{dbh}>40 \mathrm{~cm}$ were reproductive $(\mathrm{n}=84)$, whereas this was only $3.5 \%$ for those $1-40 \mathrm{~cm} \mathrm{dbh}(\mathrm{n}=280)$. Due to the strong correlation of crown position (Dawkins score) and dbh, the former was also highly associated with reproductive status: almost all (270 out of 278) reproductive trees included in the study were emergent (Dawkins score 5), and very few emergent trees were not reproductive (6 out of 276). 


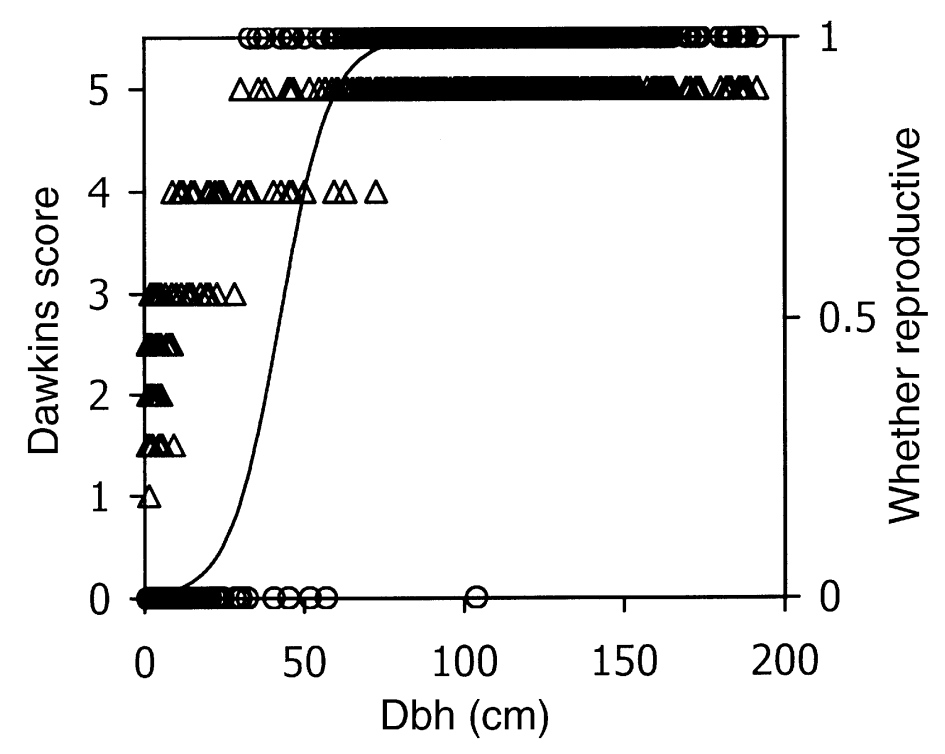

Figure 2. Relation between tree crown position, reproductive status and dbh in Bertholletia excelsa. Modified scores for the Dawkins crown illumination index $(\triangle$, left axis) and reproductive status $(\bigcirc$, right axis; whether tree has produced fruits once: $0=$ no, $1=$ yes) and a logistic regression for reproductive status (line, right axis; Constant $=-5.41$, Regression coefficient $=0.127, \mathrm{R}^{2}=0.93$ (Nagelkerke 1991)) are shown in relation to dbh. Two individuals larger than $200 \mathrm{~cm}$ dbh are not shown.

\section{Seed and seedling ecology}

Of the total production of fruits in the study plots, on average 93\% was harvested by Brazil-nut collectors (data of three fruiting periods; El Tigre: 92 99\%; El Sena: 91-97\%). Not all fruits left by the collectors were opened by agoutis. The proportion of opened fruits increased with time since fruiting (Figure 3): from 3\% in freshly fallen fruits ( $<4$ mo on forest floor), to $21 \%$ in 1 -y-old fruits and $52 \%$ in 2-y-old fruits (averaged over two sites and two data collection years).

Mean seed number per fruit equalled $18.5(\mathrm{SD}=3.3$, range: $8-26, \mathrm{n}=300)$, which is comparable to the values obtained in other areas (Leigue Gómez \& Boot, in press [18.0], Moritz 1984 [17.5-18.8], Peres \& Baider 1997 [17.1], Viana et al. 1998 [18.0]). Seed number in El Sena was somewhat higher than in El Tigre (18.8 compared to 18.1; ANOVA: $\left.\mathrm{F}_{1,294}=12.6, \mathrm{P}<0.001\right)$ but did not differ between three years $\left(\mathrm{F}_{2,294}=0.52, \mathrm{P}>0.05\right)$. The proportion of intact seeds decreased with time since fruiting (Figure 4): from approximately $95 \%$ in freshly fallen fruits to almost none in fruits that are present on the forest floor for $2 \mathrm{y}$ (c. 24-28 mo). The number of intact seeds was influenced by fruit age in both sites (ANOVA: $\mathrm{F}_{2,147}=666, \mathrm{P}<0.001$ [El Tigre], $\mathrm{F}_{2,147}=524, \mathrm{P}<$ 0.001 [El Sena]), but sites differed considerably in the number of intact seeds of 1-y-old fruits (Figure 4; 0.24 in El Tigre and 13.3 in El Sena). This may be due to the difference in fruiting period between the sites: in El Tigre the major portion of fruits falls early in the wet season (November) whereas in El Sena 
(a) El Tigre

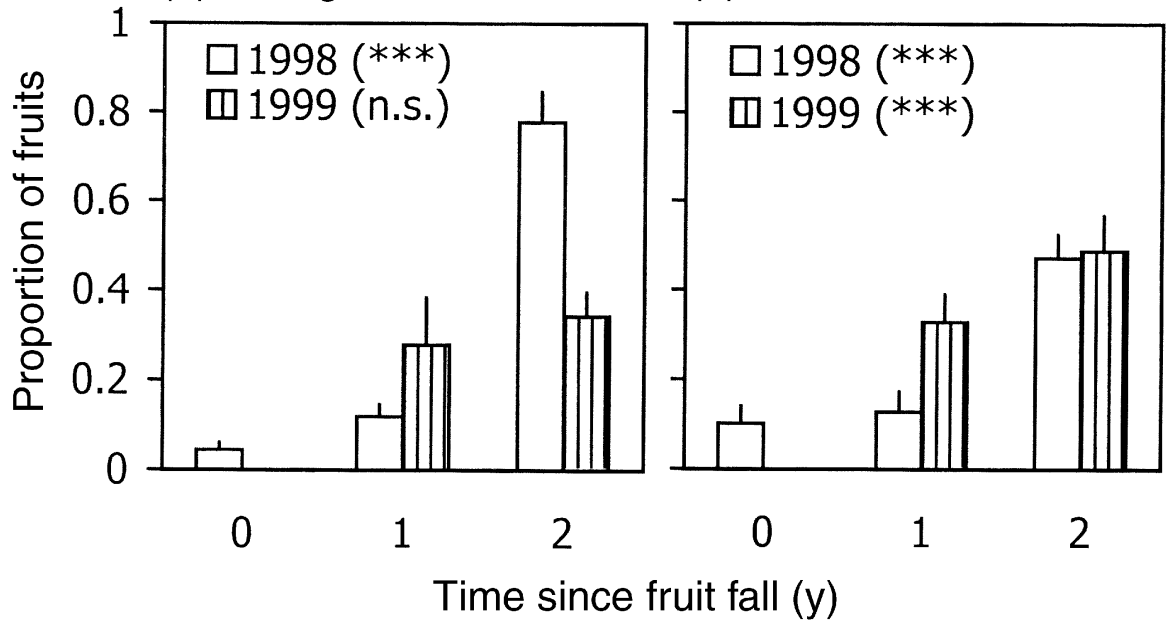

Figure 3. Proportion of fruits of Bertholletia excelsa opened by agoutis (Dasyprocta sp.) in relation to time since fruit fall, in two sites in the Bolivian Amazon where Brazil nuts are collected: El Tigre (a) and El Sena (b). Different bar types refer to data collected in different years. Significance indications (ns: not significant; ***: $\mathrm{P}<0.001)$ in the key are from $\chi^{2}$ tests for differences in the proportion of opened fruits among ages (test results $\left(\chi^{2} ; \mathrm{n}\right)$ : Tigre 1998 (117.4; 317), 1999 (4.5; 106) Sena 1998 (31.8;199), 1999 (31.9; 152)). Counts only included fruits not collected by Brazil nut collectors.

(a) El Tigre

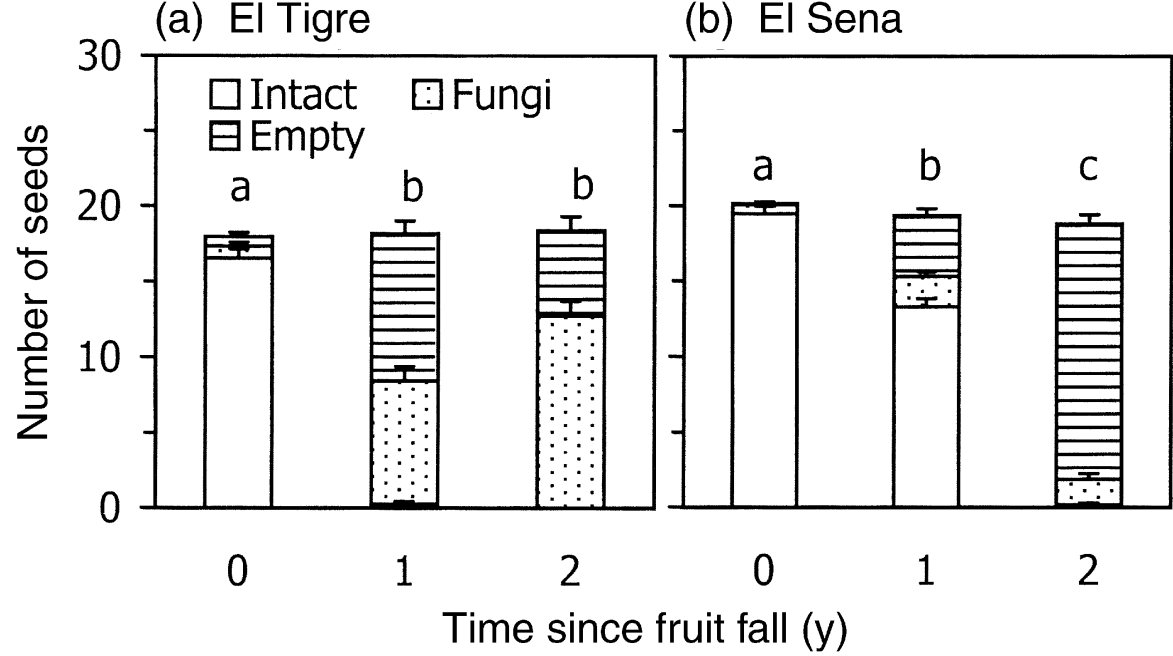

Figure 4. Seed quality in relation to time since fruit fall for Bertholletia excelsa in two sites in the Bolivian Amazon: El Tigre (a) and El Sena (b). Seeds were classified as empty (seed shell is empty; seed has completely rotted), infected by fungi and intact (no signs of damage). Different letters above bars indicate significant $(\mathrm{P}<0.05$; Tukey's HSD) differences in the number of intact seeds between years. 
this is in the middle of the wet season (January). The 1-y-old fruits in El Tigre therefore have experienced wet conditions for 2 mo longer than those in El Sena. Of the seeds that were not intact, a substantial to large part had completely rotted after $1-2 \mathrm{y}$.

The number of new seedlings per fruit that had been opened by agoutis was 3.0 for El Tigre and 0.82 for El Sena. After the dry year, the El Tigre value dropped to 0.47 whereas that in El Sena remained constant at 0.80 seedling per opened fruit. New seedlings appeared predominantly under dark forestunderstorey conditions: 97\% of the newly emerging seedlings was assigned Dawkins score 1 or 2L $(\mathrm{n}=133)$.

Fruits encountered in the study plots were highly clumped relative to adult trees (Figure 5a,b), although the degree of clumping was different for unopened and opened fruits (Kolmogorov-Smirnov test: $\mathrm{Z}=3.48, \mathrm{P}<0.001$ ). Unopened fruits were predominantly found below crowns of adult trees $(90 \%$ within $15 \mathrm{~m}$ from trunk) whereas fruits opened by agoutis were much less clumped with respect to adult trees, and a substantial proportion of these fruits was found far from adult trees $(22 \%$ at more than $35 \mathrm{~m})$. In contrast to fruits, seedlings were in general randomly distributed relative to adult trees, with a tendency for overdispersion (lower than expected abundance) at short distances from adults (Figure 5c,d). Distribution of newly recruited and existing (larger) seedlings were similar $(\mathrm{K}-\mathrm{S}$ test: $\mathrm{Z}=0.65, \mathrm{P}>0.05)$. In accordance with the difference in spatial distribution of fruits and seedlings is the finding that the occurrence of new seedlings was not higher in subplots with opened fruits than in those without (El Tigre: $\chi^{2}=1.73, \mathrm{n}=24, \mathrm{P}>0.05$; El Sena: $\left.\chi^{2}=0.03, \mathrm{n}=36, \mathrm{P}>0.05\right)$. Both results suggest that new seedlings appear at some distance from the fruits from which their seeds originated.

Size- and light-dependent survival, growth and reproduction

Survival probability increased steeply with plant size from around $50 \%$ for small seedlings (category 1), to almost 100\% in categories 3-17 (Table 1). A positive relation between seedling height and survival was found for individuals in categories $1-4$, but light level did not influence survival probability (Table 2).

Almost no mortality was observed for individuals with $\mathrm{dbh}>1 \mathrm{~cm}$ : of the 374 trees studied, only four individuals died in 2 y. Differences between sites and size-dependent patterns could therefore not be determined. However, those individuals that died were either small $(<2 \mathrm{~cm} \mathrm{dbh})$ or fairly large $(>140 \mathrm{~cm} \mathrm{dbh})$. A higher mortality risk for small $(<10 \mathrm{~cm} \mathrm{dbh})$ compared to larger trees has been found for a considerable number of tree species in Panama (Condit et al. 1995); this could be due to high damage risk or to low light availability. Large Bertholletia trees, on the other hand, gradually senesce. Signs of senescence were observed in trees of $>80 \mathrm{~cm} \mathrm{dbh:} 7 \%$ of these trees $(n=239)$ had lost one or more of their main branches (typically 2-4 for fullgrown trees). To account for the presumably higher mortality risk in small (1-9 
(a)

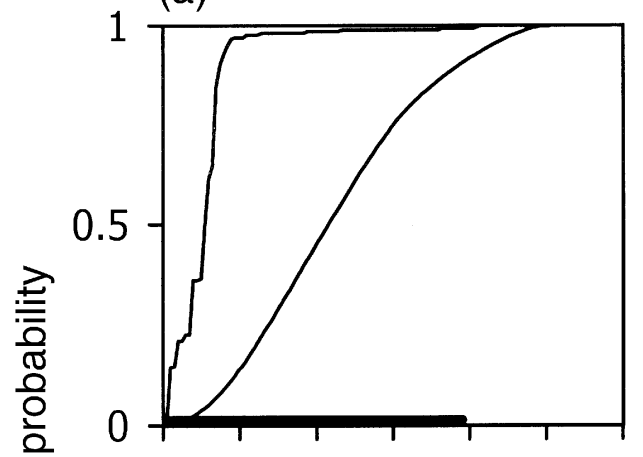

(c) (b)

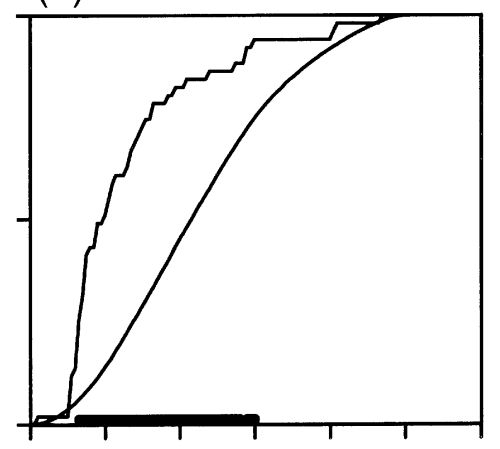

(d)

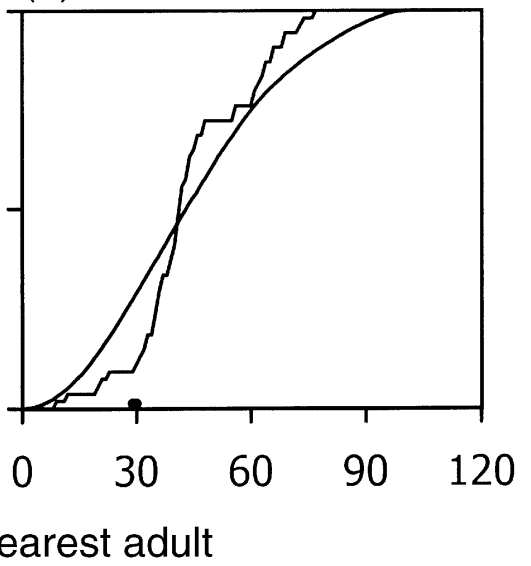

Figure 5. Spatial distribution of fruits $(\mathrm{a}, \mathrm{b})$ and seedlings (c, d) relative to adult trees of Bertholletia excelsa in study site El Tigre in the Bolivian Amazon. Observed cumulative probability of distances from fruits or seedlings to adult trees (step function, 1998 data) is compared to a theoretical distribution which assumes random distribution (smooth curve, identical for all graphs). Shown are observed distributions for fruits not opened by agoutis $(a ; n=266)$, those opened by agoutis $(b ; n=51)$; newly emerged seedlings all in size category $1(\mathrm{c} ; \mathrm{n}=76)$ and existing seedlings of at least one $\mathrm{y}$, in size categories $1-3(\mathrm{~d} ; \mathrm{n}=54)$. Clumping occurs when the observed probability is higher than the theoretical, over-dispersion when it is lower. For each distance the observed and theoretical distribution were compared by a Kolmogorov-Smirnov test: distances for which significant $(\mathrm{P}<0.05)$ differences were found are marked with the thick line along the $\mathrm{x}$-axis.

cm dbh; categories 5-7) and large (>120 cm dbh, 12-17) trees in the transition matrices, we applied a slightly lower survival rate for these size ranges. The survival probabilities used for matrix parameterization were the midpoints of the binomial 95\% confidence intervals (CI95\%) of the survival rate for small (categories 5-7), medium-sized (8-14) and large (15-17) trees (CI95\%: 0.969$1.000 ; 0.990-1.000$ and $0.970-0.998$, respectively).

Seedling height growth was highly variable within size categories (Figure 6), as indicated by high coefficients of variation (CV) ranging from 75-322 $($ mean $=164)$. Maximum growth rates were very high, often amounting to more than $40 \mathrm{~cm} \mathrm{y}^{-1}$, being one order of magnitude higher than the average 


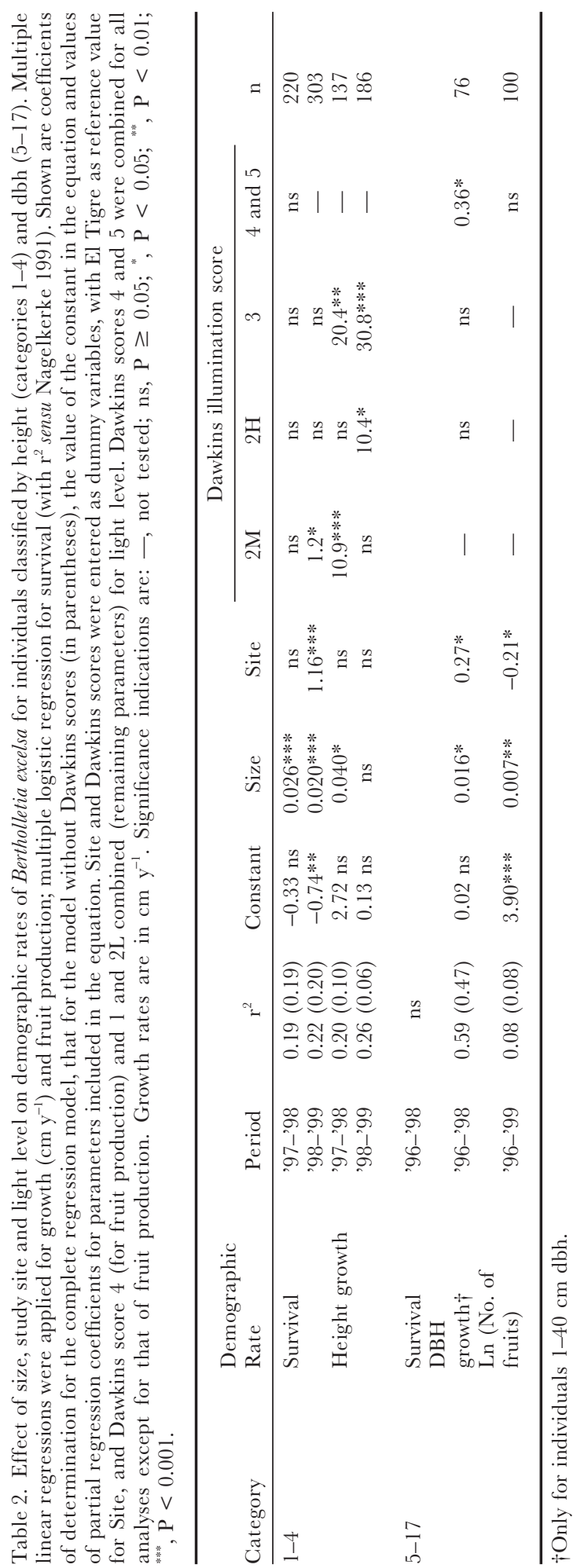


(a) El Tigre

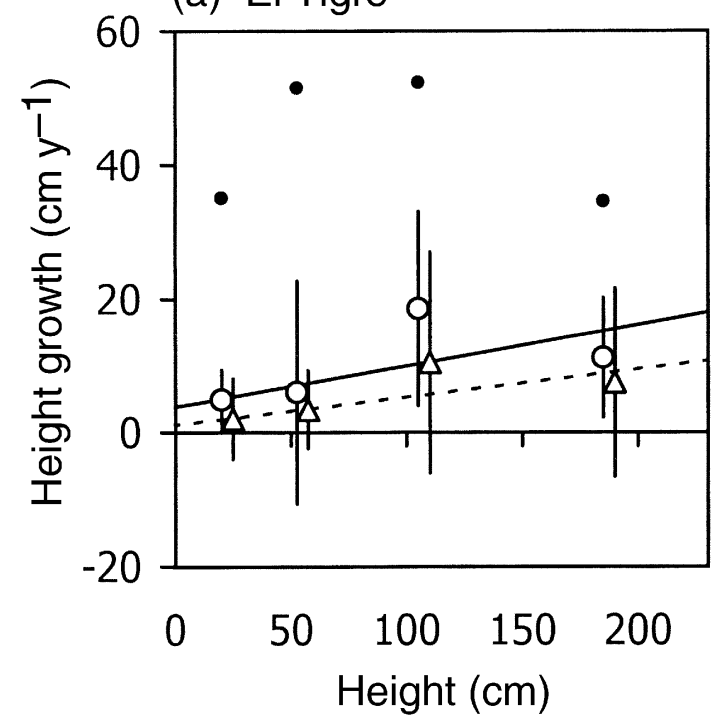

(b) El Sena

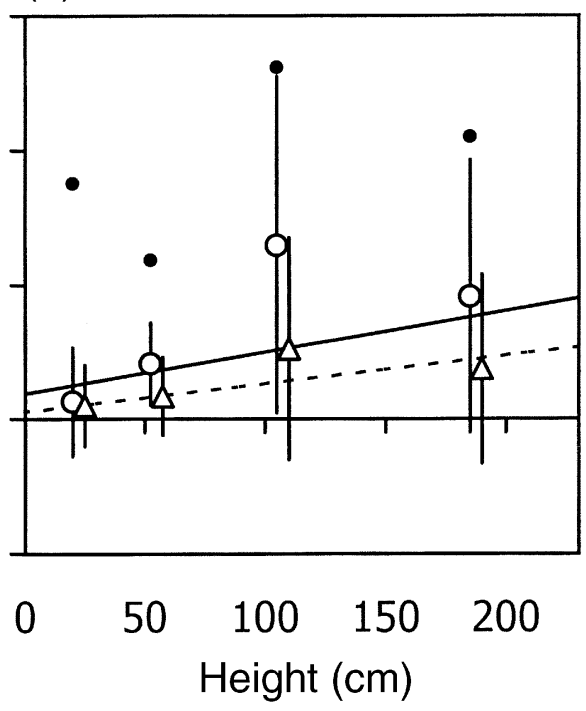

Figure 6. Size-dependence of seedling height growth in Bertholletia excelsa in two sites in the Bolivian Amazon: El Tigre (a) and El Sena (b). Shown are mean growth $( \pm 1$ SD) for categories $1-4$ in a normal $(\bigcirc)$ and a dry year $(\triangle)$, linear regressions for normal (drawn line; Growth $=3.77+0.062 \times$ Height, $\mathrm{R}^{2}=0.10$ ) and dry year (broken line; Growth $=1.04+0.042 \times$ Height, $\mathrm{R}^{2}=0.06$ ) and maximum growth rate observed per category for both years together $(\mathbf{O})$. Regression lines are not different between sites.

for some categories. The high variation in growth rates reflected the high variation in light level received by seedlings (Table 1). Light level had a large influence on seedling growth in regression models: adding Dawkins illumination scores to a model with plant size alone substantially increased the proportion of variation explained (Table 2).

Growth in dbh also showed considerable variation, both among and within size categories (Figure 7). Growth rate increased up to $c .60 \mathrm{~cm}$ dbh and then gradually declined. In the size range with high growth rate $(30-60 \mathrm{~cm} \mathrm{dbh})$, annual dbh increments of $>1.5 \mathrm{~cm}$ were often observed. The peak in the growth curve was wider and more pronounced in El Sena than in El Tigre, and observed maximum growth rates were higher in the former site (2.64 compared to $1.86 \mathrm{~cm} \mathrm{y}^{-1}$ ). The reason for a less pronounced peak for El Tigre is probably that high growth values were restricted to a narrow dbh range and were therefore not detected by the Hossfeld growth curve that has limited flexibility (Zeide 1993).

Between-site differences in dbh growth pattern were assessed by comparing the residual variation of the site-specific Hossfeld models as presented in Figure 7 with that of a model in which data for both sites were combined. The site-specific models accounted for significantly more variation $\left(\mathrm{F}_{3,291}=7.2 ; \mathrm{P}<\right.$ 0.001 ), indicating that equations differed between sites. A site effect on dbh growth was also obtained in a linear regression using only trees in the increasing leg of the growth-size curve $(1-40 \mathrm{~cm}$ dbh; Table 2), with the El Sena growth rate being higher. 


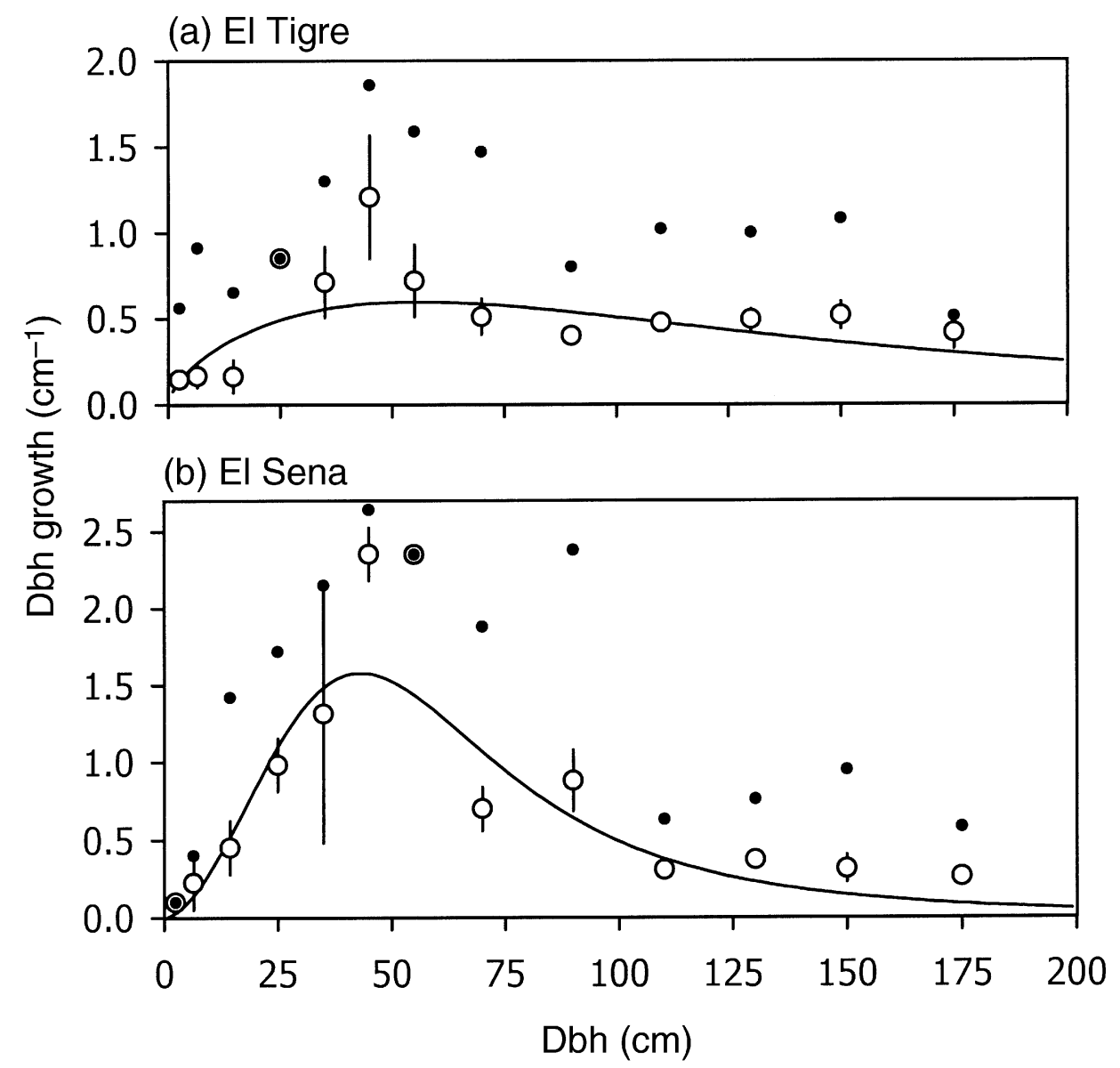

Figure 7. Size-dependent pattern in dbh growth in Bertholletia excelsa in two sites in the Bolivian Amazon: El Tigre (a) and El Sena (b). Shown are fitted Hossfeld IV equations (lines), observed average ( \pm 1 SD) growth rate $(\bigcirc$; for categories $5-17)$ and observed maximum growth rate $(\mathbf{O})$. Fitted parameters $a, b$ and $c$ (eqn. 1) equalled 133.7, 20.8 and 1.61, respectively, for the El Tigre $\left(\mathrm{R}^{2}=0.23, \mathrm{n}=167\right)$ and $119.1,422.5$ and 2.67 for El Sena $\left(\mathrm{R}^{2}=0.41, \mathrm{n}=130\right)$.

Light levels received by Bertholletia trees shifted from being generally low and highly variable for pole-sized trees (categories 5-6) to very high and restricted to one Dawkins score for large emergent trees (12-17; Table 1). For example, pole-sized trees were assigned to as many as five Dawkins illumination scores. Variation in light availability for trees of $1-40 \mathrm{~cm}$ dbh explained part of the observed variation in dbh growth (Table 2).

Production of fruits was highly variable among individuals (averaged over 3 y: geometric mean $=102 ;$ CI95\%: 21.5-474.4; $\mathrm{n}=102$; maximum $=1032$ by tree of $125 \mathrm{~cm} \mathrm{dbh}$ ) and within individuals over the three measurement years (average $\mathrm{GV}=71.4, \mathrm{n}=102$; extreme example of production of 31 fruits followed by 1003 fruits). But fruit production at population level was much less variable (cf. Leigue Gómez \& Boot, in press). In each of the measurement years, a certain proportion of the reproductive individuals (mostly different 
individuals each year) did not produce any fruits: this proportion did not differ among years (Cochran test: $\mathrm{Q}=0.55, \mathrm{P}>0.05$ ) and averaged $7.5 \%$. After excluding these non-productive trees, fruit production was related to tree size in a regression analysis: $\mathrm{dbh}$ and site differences explained only a small part of the large variation in fruit production (Table 2). For this analysis and for matrix parameterization, trees of $40-60 \mathrm{~cm}$ dbh were excluded as they sporadically produced fruits, and if so, only produced few fruits.

\section{Differences between years}

Seedling growth was strongly affected by the dry year: average growth was 4.7 (El Tigre) and $3.0 \mathrm{~cm} \mathrm{y}^{-1}$ (El Sena) lower during the dry measurement year (Wilcoxon matched pairs test: $\mathrm{Z}=-2.01, \mathrm{n}=68, \mathrm{P}<0.05$; and $\mathrm{Z}=-2.95, \mathrm{n}=$ $35, \mathrm{P}<0.01$, respectively). Seedling survival was only different between years for El Tigre $\left(\sigma_{\text {normal }}=0.73, \sigma_{\text {dry }}=0.57 ; \chi^{2}=9.55, \mathrm{n}=355, \mathrm{P}<0.01\right)$, but not for El Sena $\left(\sigma_{\text {normal }}=0.64, \sigma_{\text {dry }}=0.76 ; \chi^{2}=3.05, \mathrm{n}=202, \mathrm{P}>0.05\right)$. The most severely affected variable was the abundance of newly recruited seedlings, which was much lower after the dry year: in El Tigre by $80 \%$ (5.3 $\mathrm{ha}^{-1}$ compared to $\left.25.8 \mathrm{ha}^{-1}\right)$; in El Sena by $56 \%\left(7.0 \mathrm{ha}^{-1}\right.$ compared to $\left.16.0 \mathrm{ha}^{-1}\right)$.

Differences in tree growth were smaller: in the El Tigre dry year dbh growth was slightly reduced (difference $=0.11 \mathrm{~cm} \mathrm{y}^{-1}$; Wilcoxon: $\mathrm{Z}=-4.23, \mathrm{n}=184, \mathrm{P}$ $<0.001$ ) whereas in El Sena it was somewhat higher (difference $=0.14 ; \mathrm{Z}=$ $-3.92, \mathrm{n}=149, \mathrm{P}<0.001)$. Variation between sites in rainfall distribution over the year and severity of the dry year may in part have been responsible for this finding. Since observed differences are relatively small compared to measurement errors and as the reliability of dbh increment data is considerably improved when calculated over several years, growth data of different years were pooled.

\section{Matrix model output}

Four transition matrices were constructed (Table 3): per site, one for a normal $(\mathbf{N})$ and for a dry year $(\mathbf{D})$. Normal- and dry-year matrices differed in seedling growth and survival (categories 1-4), and for recruitment of new seedlings. Matrices of the two study sites differed in all demographic rates except for tree survival (categories 5-17) and seedling height growth (categories 1-4).

Population growth rates $(\lambda)$ of the four time-invariant matrix models were all close to one $\left(\lambda_{\text {Tigre }, \mathrm{N}}=1.017 ; \lambda_{\text {Tigre }, \mathrm{D}}=0.995 ; \lambda_{\text {Sena }, \mathrm{N}}=1.007 ; \lambda_{\text {Sena, } \mathrm{D}}=1.004\right)$. Population growth rate in El Tigre fluctuated more with year type, in accordance with the stronger changes in seedling demography there during the dry year. Elasticity analysis for the normal-year matrices of both study sites showed that the stasis elements in the transition matrices (those elements that contain the probability that individuals stay in the same category) had the largest influence on population growth (Figure 8). Growth and fecundity were much less important in determining the population growth rate $(\lambda)$. This low sensitivity of reproduction on population growth rate suggests that collection 


\begin{tabular}{|c|c|c|}
\hline 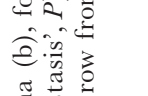 & 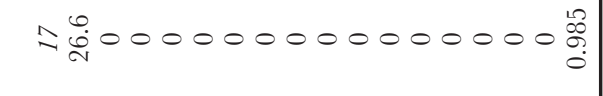 & $=9.000000000000000 \frac{8}{8}$ \\
\hline 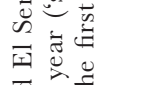 & 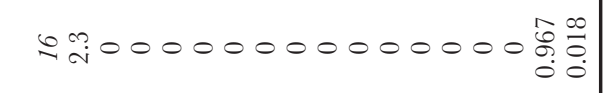 & 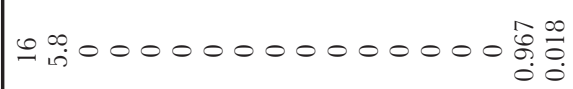 \\
\hline$\stackrel{.}{g}$. & : & 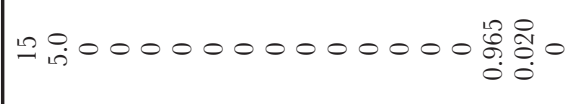 \\
\hline & 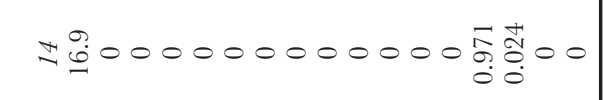 & 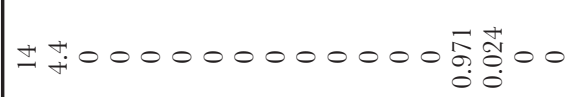 \\
\hline 0 & 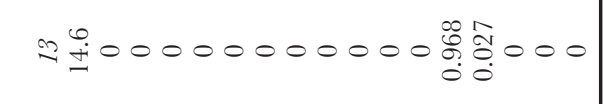 & m \\
\hline 5 & 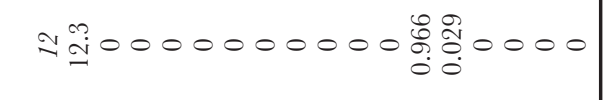 & 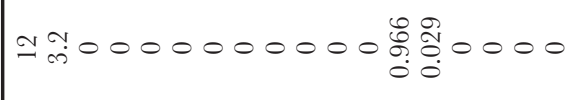 \\
\hline$\sigma$ & 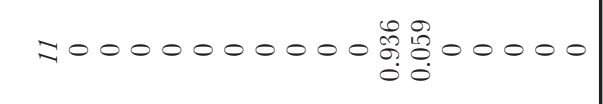 & $=0000000000 \stackrel{0}{0} 0$ \\
\hline$\Xi \tau$ & R0000000000 & 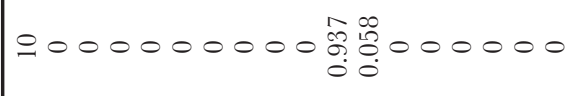 \\
\hline$\tilde{0}$ & $000000000 \frac{0}{0}: 0000000$ & $000000000 \frac{9}{9} 0000$ \\
\hline 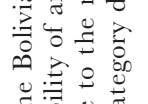 & 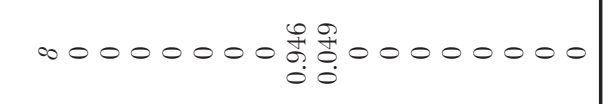 & 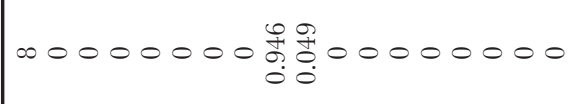 \\
\hline$\tilde{b} \xi$ & 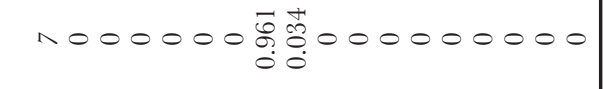 & $1000000 \frac{\overrightarrow{8}}{0}: \frac{0}{0} 000000000$ \\
\hline$\frac{5}{0}$ & 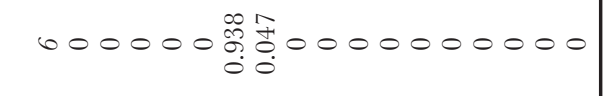 & 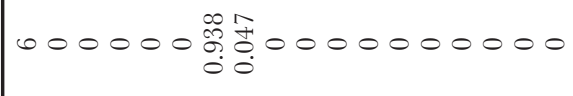 \\
\hline$\Xi$ & $n 0000 \frac{0}{0}+\frac{0}{0} 00000000000$ & $n 0000 \frac{\vec{g}}{0}+00000000$ \\
\hline 寻 & M000 & 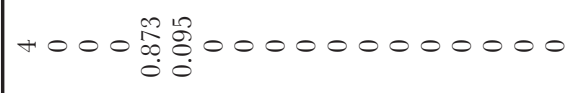 \\
\hline $\bar{v}$ & 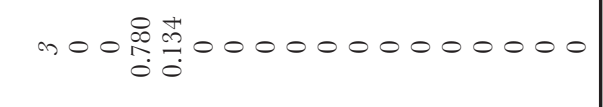 & mo0 \\
\hline & 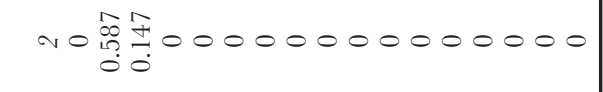 & vo 品 \\
\hline$\Xi$ & - 隺哥000000000000000 & 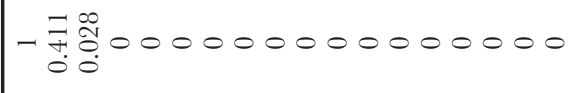 \\
\hline 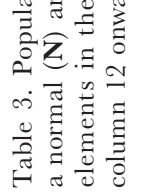 & 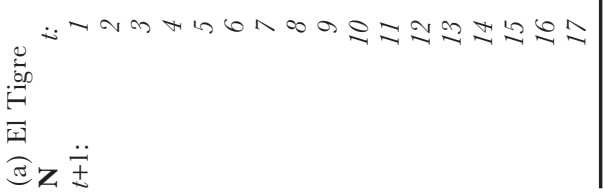 & 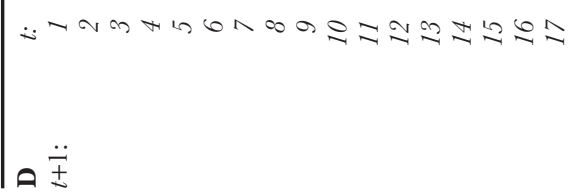 \\
\hline
\end{tabular}




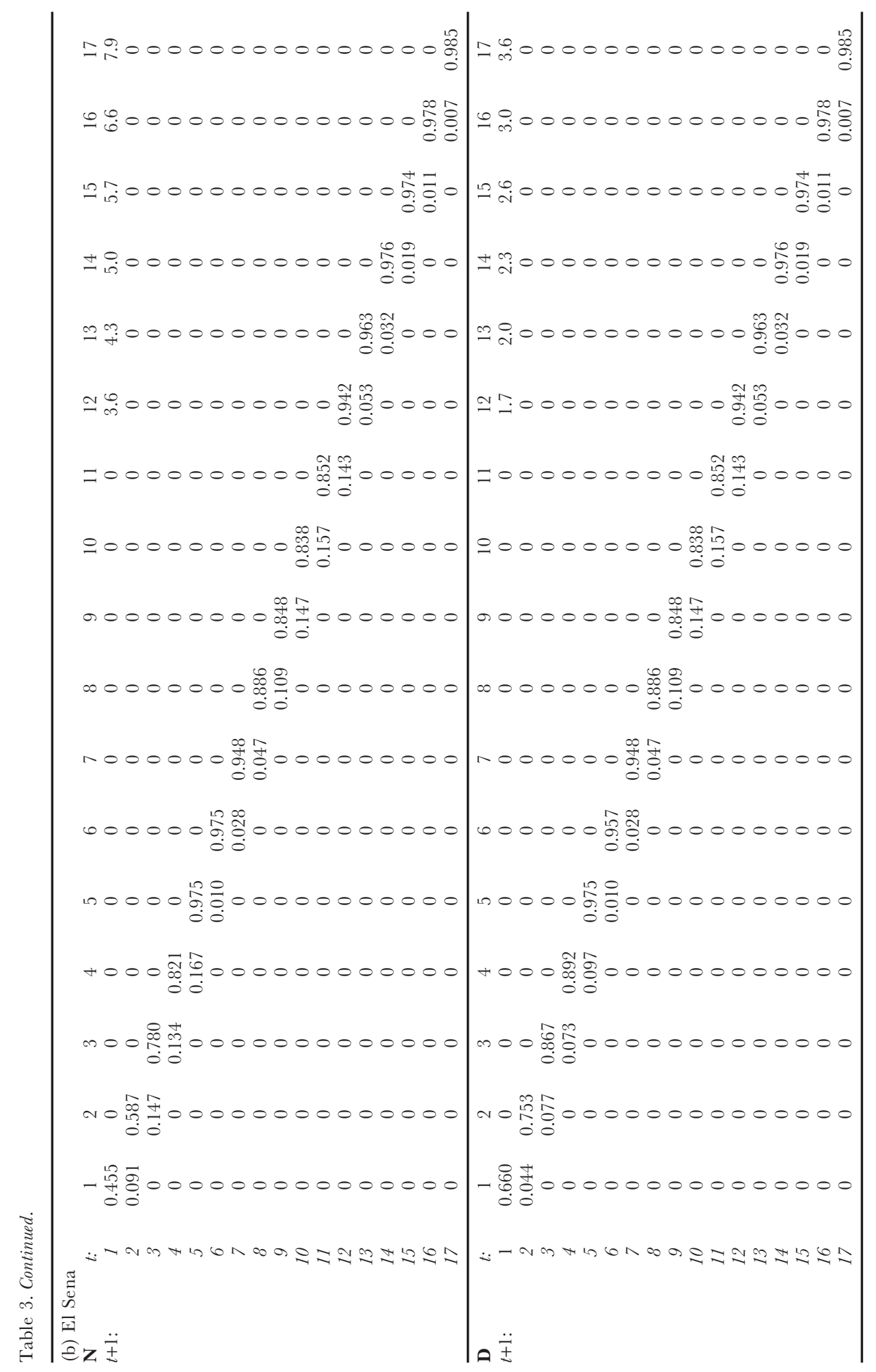




\section{(a) El Tigre}

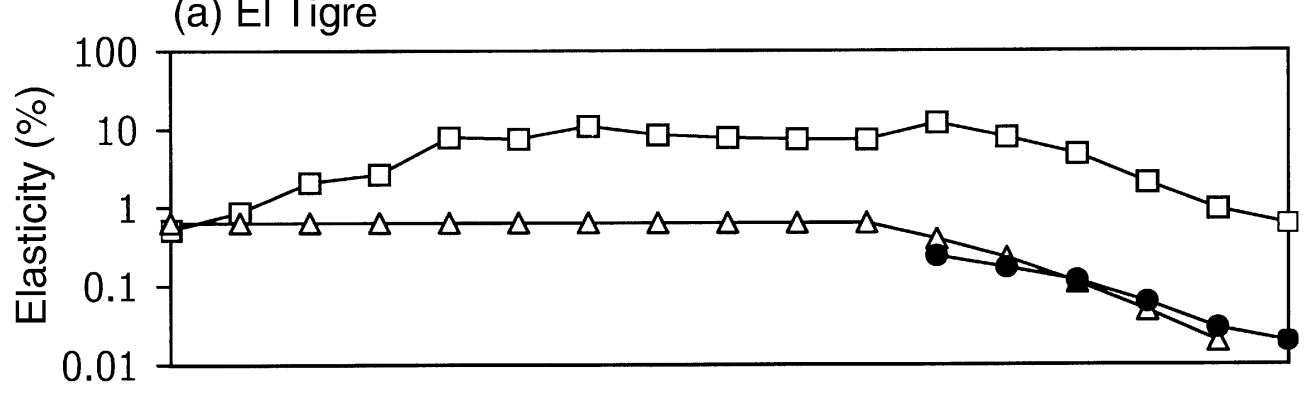

(b) El Sena

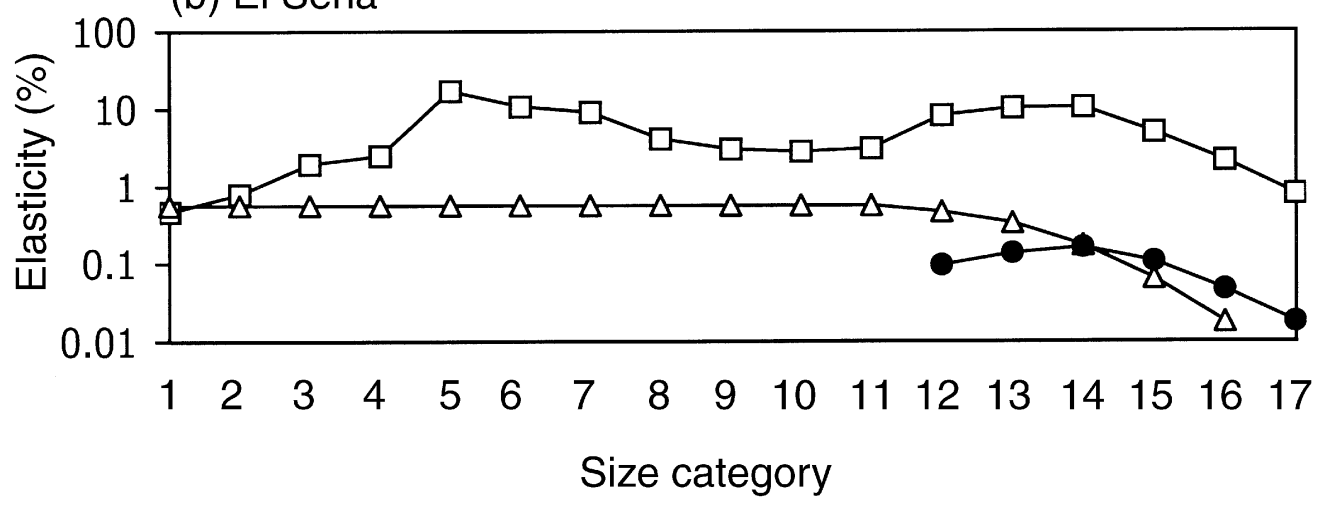

Figure 8. Elasticity values for population matrix models of Bertholletia excelsa in two sites in the Bolivian Amazon, El Tigre (a) and El Sena (b), for a year with normal precipitation. Shown are elasticity values (as percentages) for stasis $(\square)$, growth $(\triangle)$ and fecundity $(\bullet)$ elements. A higher value implies a higher sensitivity of the population growth rate to a proportional change in that matrix element.

of Brazil nuts has a low impact on the maintenance and growth of the entire population.

Age calculations based on the normal-year matrix models revealed that estimated age at entering the first reproductive category (12) equalled 141 $( \pm 47,1$ SD) y for El Tigre and $126( \pm 51)$ y for El Sena (Figure 9). Mean age in the last size category was estimated to be $360( \pm 106)$ and $362( \pm$ 115) y, respectively. It should be noted that the standard deviations given for age estimates are based on the variation in the number of time steps needed to reach a certain category, and do not include among-individuals variation in demographic rates (Cochran \& Ellner 1992). Age estimates based on growth equations were very similar to those based on matrix models, although they tended to be somewhat higher for the last two categories (Figure 9).

Time-varying stochastic matrix models yielded mean population growth rates $\left(\log \left(\lambda_{\mathrm{s}}\right)\right)$ intermediate between $\log$-transformed population growth rates $(\lambda)$ for normal- and dry-year matrix models: $0.014(\mathrm{SD}=0.138)$ for El Tigre and $0.006(\mathrm{SD}=0.021)$ for El Sena. Population growth varied considerably, especially for El Tigre where demography was more strongly affected in the 
(a) El Tigre

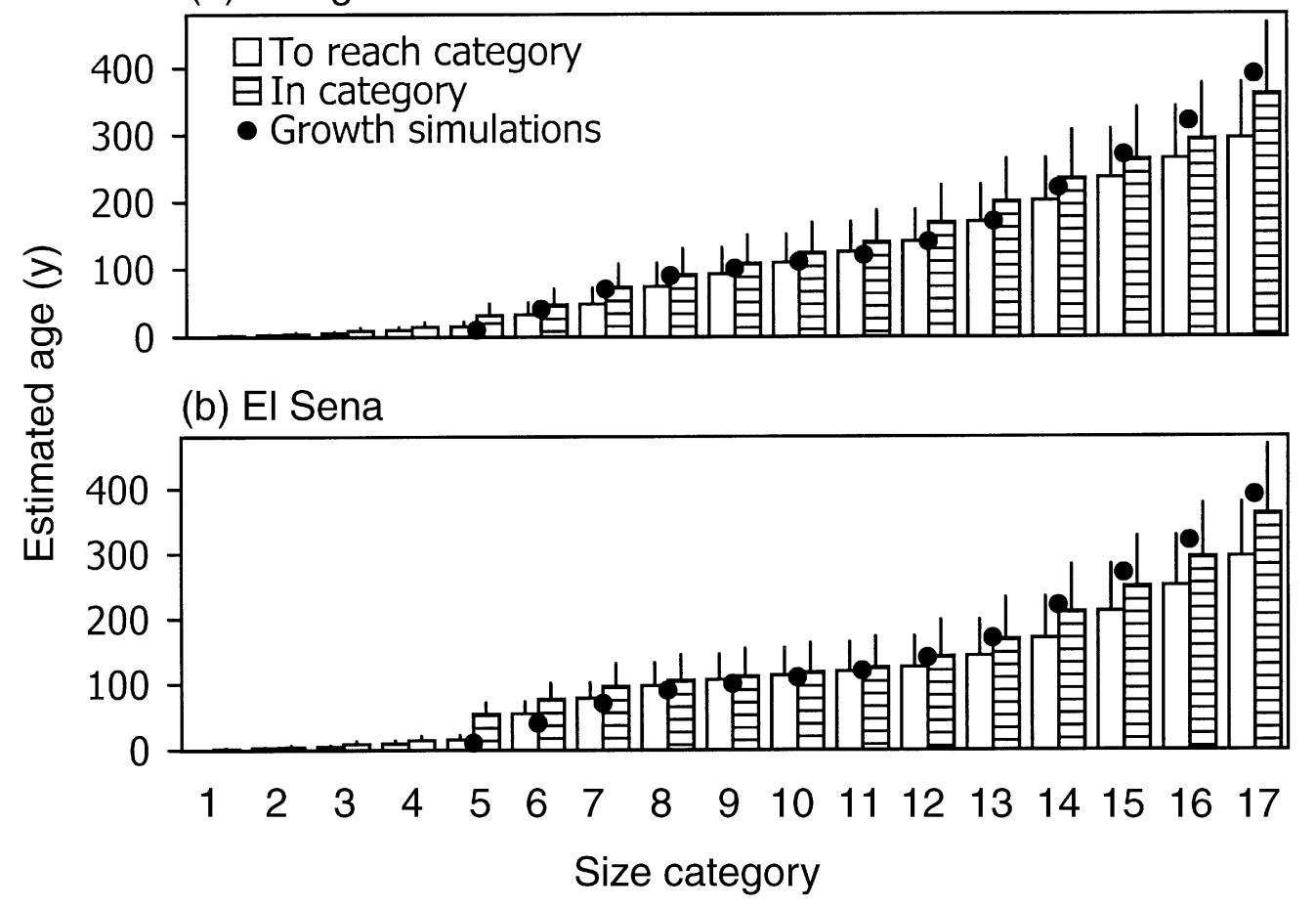

Figure 9. Age estimates of Bertholletia excelsa in two sites in the Bolivian Amazon: El Tigre (a) and El Sena (b). Bars denote the mean age at reaching a category and the mean age in a category (both \pm 1 SD; denoted $\tau$ and $S$, respectively, in Cochran \& Ellner 1992). Closed dots $(\mathbf{)})$ denote the average for the midpoint of each dbh category using growth simulations (following Lieberman et al. 1985; using 1000 simulations and a 'window size' of seven trees). Growth data (of trees $>1 \mathrm{~cm}$ dbh) of both sites were pooled to obtain a sufficiently large sample size.

dry year. For both study sites, the value zero was included in the interval mean $\pm 1 \mathrm{SD}$ of the stochastic growth rates, indicating that, given a dry-year frequency $(\pi)$ of 0.12 , population sizes are likely to be stable when considered over a long period.

Stable stage distributions generated by matrix models resembled the observed population structure in the study plots well, though not very closely (Figure 1). The 'hump' in the size distribution, i.e. the higher density of trees in categories 12-16 compared to those in 7-11, was also obtained in the stable stage distributions, being more pronounced for El Sena than for El Tigre. Differences between stable stage distributions resulting from standard matrix models and from stochastic time-varying models were generally small and more pronounced in seedling categories that were most affected by the dry year. 


\section{DISGUSSION}

Regeneration in exploited populations

A very high proportion (on average 93\%) of the total seed production is removed by collectors from the two exploited Bertholletia populations under investigation. Although this value may vary with total fruit production, price paid to collectors and number of collectors working in the area, it was rather constant over $3 \mathrm{y}$ and two sites. Of the fruits left by Brazil-nut collectors, almost half are not opened by agoutis at all, and only a small fraction is opened shortly after fruit fall (Figure 4). The majority of fruits that are gnawed open by agoutis are 1-2 y old. Agoutis may leave fruits on the forest floor in order to reduce energetic costs of opening them, since the fruit's woody pericarp gradually softens. However, the risk of this 'waiting strategy' is that a large proportion of seeds in 1-2 y old fruit are infected by fungi or rot completely. Thus, a trade-off may exist for agoutis between the costs to release seeds and seed quality, resulting in a time window for seed release and dispersal, perhaps around $1 \mathrm{y}$ after seed fall. Clearly, additional studies on seed dispersal are needed to confirm this hypothesis.

The difference in spatial distribution of fruits opened by agoutis and those not opened (Figure 5) suggests that agoutis may transport some of the fruits before opening them and scatterhoarding the seeds. This behaviour is confirmed by seed dispersal studies in Peru (Ortiz 1995). In seed predation experiments, agoutis scatterhoard Bertholletia seeds at a maximum distance of 20-40 m from seed deposits (Bouwman \& van Dijk 1999, Peres \& Baider 1997, Peres et al. 1997), although the majority is found at much shorter distances.

Fruits left by Brazil-nut collectors and new seedlings differed greatly in their spatial distribution, the former being highly clumped around parent trees and the latter randomly dispersed. The more diffuse dispersion pattern in seedlings may be the result of primary (and secondary) dispersal (cf. Hamill \& Wright 1986, Peres \& Baider 1997), a higher removal rate of cached seeds close to adult trees (cf. Howe \& Smallwood 1982, Peres et al. 1997), more cotyledon predation of recently emerged seedlings at high density or close to adult trees (as cotyledons become part of the stem, cotyledon predation kills the individual; cf. Howe \& Smallwood 1982, Oliveira 2000), and spatial variation in light conditions. 'Dispersal' of Bertholletia seeds by Brazil-nut collectors may also have contributed to the observed difference in spatial distribution of fruits and seedlings. As collectors open fruits or carry bags filled with seeds through the forest, they may unintentionally leave or drop seeds. This dispersal activity is considered to be an important contribution to tree regeneration (Ortiz 1995), but field evidence is still lacking.

Bertholletia seedling dynamics were characterized by high rates of recruitment and mortality. For example, in 1998 new seedlings accounted for 68\% of the seedlings in category 1 in El Tigre, but $65 \%$ of these seedlings died within one (dry) year. High turnover rate in seedlings and strong influence of climatic 
circumstances cause seedling abundance to vary greatly in time, implying that seedling abundance alone is an unreliable indicator for Bertholletia regeneration potential, although this is sometimes taken as such (Mostacedo \& Fredericksen 1999).

\section{Bertholletia demography}

The demography of Bertholletia is characterized by a highly variable growth rate for seedlings to medium-sized $(\mathrm{dbh}<50 \mathrm{~cm})$ trees. The variability in growth is partly explained by variation in light availability, which is high for saplings and medium-sized trees (Table 1, Viana et al. 1998). Maximum seedling and sapling height growth observed in this study often exceeded $40 \mathrm{~cm} \mathrm{y}^{-1}$ and is comparable to values obtained for Bertholletia seedlings under experimental high-light conditions (Poorter 1999) and in abandoned agricultural fields (Kainer et al. 1998, Peña-Claros et al., in press). The maximum dbh growth rates found here $\left(>2 \mathrm{~cm} \mathrm{y}^{-1}\right.$ in El Sena; $>1.5 \mathrm{~cm} \mathrm{y}^{-1}$ in El Tigre) are remarkably high compared to other neotropical non-pioneer tree species (Clark \& Clark 1999, Korning \& Balslev 1994, Lieberman et al. 1985). Plasticity in growth and a high maximum growth rate are important traits for an adequate response to increased light availability, necessary to compete with neighbouring plants when a treefall gap is formed (Denslow 1987). These characteristics place Bertholletia in the least shade-tolerant portion of the continuum of climax (non-pioneer) tree species (Whitmore 1989), and support its classification as a gap-dependent (Mori \& Prance 1990) or light-demanding (Kainer et al. 1999, Salomao 1991) species. Results from a gap inventory in one of the study sites (El Tigre) confirm the gap-dependence of Bertholletia: Myers et al. (2000) found that sapling (height $>130 \mathrm{~cm}$ ) density increased with gap area and light availability whereas seedling abundance was indifferent to these factors.

Bertholletia demography is furthermore characterized by a long life span: large trees $(>160 \mathrm{~cm}$ dbh) may age over three centuries and age at entering the first reproductive category $(60-80 \mathrm{~cm} \mathrm{dbh})$ is more than $120 \mathrm{y}$, according to two types of age estimates (Figure 9). Trees in the most abundant adult size categories in the study sites averaged an estimated $200 \mathrm{y}$. These ages are much higher than those reported for fully reproductive Bertholletia trees in plantations, which range from 11 (grafted) to 30 y (Mori \& Prance 1990 and references therein).

There are some important assumptions for both ageing techniques used. The matrix-based method (bars in Figure 9) uses two simplifying characteristics intrinsic to matrix models. Firstly, the method uses average values for demographic rates (survival, growth and reproduction) and cannot cope with variation in these parameters. This simplification may generate somewhat higher age estimates when population maintenance is dependent on individuals with above-average growth to reach the canopy. Secondly, in matrix models 
individuals 'forget their past', i.e. performance of an individual is not autocorrelated in time, causing slow-growing individuals to be able to abruptly speed up and jump to successive categories in short time. Similarly, matrix models also allow individuals to have biologically impossible life histories, e.g. completing their entire life cycle in as few time steps as there are categories or to stay in one category for $100 \mathrm{y}$ (when stasis probability equals 0.95 , about $(0.95)^{100} \cong 0.5 \%$ of individuals stay for $100 \mathrm{y}$ in that category). These unrealistic life histories increase the variation in age estimates (Zagt 1997) and are especially important for categories with high stasis probability (Boucher 1997).

As for the matrix-based ageing method, individual trees in the growthsimulation method (dots in Figure 9) 'forget their past', which could lead to unrealistic growth trajectories. Secondly, in its standard form, this method does not include the influence of tree mortality on the age estimations.

In spite of the above drawbacks of the two ageing methods, Bertholletia life span is undoubtedly very long, as adult stature is large and adult growth rate is typically low $\left(\geq 0.5 \mathrm{~cm} \mathrm{y}^{-1}\right)$. Our age estimates are supported by the only ${ }^{14}$ C-dated Bertholletia individual (Camargo et al. 1994). This tree of $225 \mathrm{~cm}$ dbh was estimated to be $440 \pm 60$ y (mean $\pm 1 \mathrm{SD}$ ), suggesting a life-long dbh growth of $0.6 \mathrm{~cm} \mathrm{y}^{-1}$ for this tree. When applying this rate to the midpoints of size categories with reproductive trees, comparable ages are found (117 and 292 y for trees of 70 and $170 \mathrm{~cm} \mathrm{dbh}$, respectively). Clearly, many more individuals should be ${ }^{14} \mathrm{C}$-dated to determine age distributions of different-sized Bertholletia trees.

The commonly observed higher abundance of certain adult classes in size distributions of Bertholletia populations, has been interpreted as the result of past Amerindian cultivation of the species (Clay 1997) or of large-scale disturbances necessary for regeneration (Mori \& Prance 1990, Peres \& Baider 1997). The low abundance categories typically found in Bertholletia populations (DHV 1993, Peres \& Baider 1997, Pires 1984, Salomao 1991, van Rijsoort et al. 1993, Viana et al. 1998; Figure 1), coincide with the peak in dbh growth for trees of 30-60 cm dbh (Figure 7). Similarly, the typical 'hump' of adult trees in Bertholletia size distributions (references as above) matches with the decreasing growth rate at increasing size for trees $>60 \mathrm{~cm}$ dbh. Thus, by rapidly growing through certain categories and slowly through others, respectively low and high densities are obtained. The stable stage distributions from our matrix models (Figure 1) show that the typical Bertholletia population structure can be generated by size-dependent growth patterns (see also Caswell 1989, p. 105). The weaker 'hump' in the stable stage distribution for El Tigre is probably the result of the less-pronounced dbh growth curve for this population (Figure 7).

\section{Impact of extraction on future nut production}

The impact of nut extraction on future availability of Brazil nuts from natural populations is not easily quantified, as seed removal is not the only effect 
of exploitation. Apart from extracting nuts, Brazil-nut collectors also commonly hunt agoutis and they may act as 'seeders' when dropping harvested Brazil nuts (Ortiz 1995). The latter activity increases possibilities for recruitment, but the extent to which this contributes to Bertholletia regeneration is unclear and probably small. Also the effect of lower agouti density on Bertholletia regeneration is not known. Furthermore, the reduction in Bertholletia seed availability may change seed handling by agoutis (cf. Forget 1996). In a seedremoval removal experiment in El Tigre, the proportion of scatterhoarded seeds to consumed seeds (a measure for agouti dispersal activity) decreased with the density at which Bertholletia seeds were offered (Bouwman \& van Dijk 1999). This implies that the number of scatterhoarded seeds - those that have prospects for germination - is diminished first by the collection of Brazil nuts, and probably furthermore by changes in agouti seed handling.

The complex changes in exploited Bertholletia populations make it difficult to carry out simple numeric manipulations of seed production in matrix models to determine demographic consequences of exploitation, as has been conducted for several non-timber forest products (Bernal 1998, Peters 1990a,b). However, using the demographic information collected in the two exploited Bertholletia populations studied and the matrix model analyses, the impact of exploitation can be assessed indirectly.

Firstly, the maintenance and growth of an exploited population is rather insensitive to changes in reproduction, but very sensitive to small changes in the probability of staying in a certain size category (Figure 8). This is typical in long-lived species (Silvertown et al. 1993), and would therefore also have been found for an unharvested study population. As population growth rate is insensitive to changes in fecundity for tree species, simulations of heavy seed harvests generally result in very small reductions of the population growth (Bernal 1998, Peters 1990a,b). However, results of such simulations should be interpreted with great care as population growth in these cases strongly depends on the survival probability in the last categories. Survival rate in these categories is typically high for long-lived trees and appears to be partly responsible for the low reduction in population growth when simulating seed harvests (Zagt 1997, Zuidema 2000).

Secondly, age estimates presented here indicate that Bertholletia trees may age over a century before producing a considerable number of fruits (at 60-80 $\mathrm{cm} \mathrm{dbh}$ ), and that the period during which trees are reproductive is long, often amounting to over 150 y (Figure 9). This implies that it will take very long before changes in production of fruits as a result of exploitation can be detected in the number of fruits produced.

Thirdly, in exploited populations, recruitment does take place: there is input of new seedlings and individuals of all size categories can be found in exploited populations. Furthermore, matrix models for exploited populations do not predict shifts in population structure over time (Figure 1), as was found for simulations of fruit harvests in other tree species (Peters 1996). We therefore expect 
that current extraction practices will not lead to future changes in size distribution.

In conclusion, the results of this study suggest that high levels of Brazil-nut extraction may be sustained at least for several decades without reducing production potential and that there are good prospects for continued regeneration of exploited populations, which would safeguard productivity for even longer periods.

\section{ACKNOWLEDGEMENTS}

We are very grateful to all members of the fieldwork team: Luis Apaza, Rene Aramayo, Miguel Cuadiay, Nico Divico, James Joffrey, Alejandro Hayashida, Nazareno Martinez, Jeannette van Rijsoort, Thomas Stockman, Saida Ugueto, Corien van Zweden and others. Furthermore we thank Jhon Leigue Gómez for sharing data on fruit production in El Tigre, Roderick Zagt for programs to derive matrix age estimates and Heinjo During for programming the growth simulations. Wim Dijkman, Milton Lieberman, Marinus Werger, Roderick Zagt and an anonymous reviewer gave valuable comments on previous versions. This study was partly funded by grant BO 009701 from the Netherlands Development Assistance.

\section{LITERATURE GITED}

ASSIES, W. 1997. Going nuts for the rainforest. Non-timber forest products, forest conservation and sustainability in Amazonia. Thela, Amsterdam. 96 pp.

BEEKMA, J., ZONTA, A. \& KEIJZER, B. 1996. Base ambiental para el desarollo. Departamento de Pando y la Provincia de Vaca Diez. Cuaderno de Trabajo 3, SNV, La Paz. 91 pp.

BERNAL, R. 1998. Demography of the vegetable ivory palm Phytelephas seemannii in Colombia, and the impact of seed harvesting. Journal of Applied Ecology 35:64-74.

BOJANIC HELBRINGEN, A. 2001. Balance is beautiful: accepting sustainable development in the rainforest of the Bolivian Amazon. Ph.D. thesis, Utrecht University, Utrecht. 260 pp.

BOOT, R. G. A. \& GULLISON, R. E. 1995. Approaches to developing sustainable extraction systems for tropical forest products. Ecological Applications 5:896-903.

BOUCHER, D. H. 1997. General patterns of age-by-stage distributions. Journal of Ecology 85:235-240.

BOUWMAN, M. \& DIJK, S. VAN 1999. Removal and fate of Brazil nut seeds (Bertholletia excelsa) exposed in two contrasting seed densities in a Bolivian moist forest. M.Sc. thesis, Utrecht University, Utrecht. 26 pp.

BROEKHOVEN, G. 1996. Non-timber forest products. Ecological and economic aspects of exploitation in Colombia, Ecuador and Bolivia. IUCN, Gland. 126 pp.

BUCKLEY, D. P., O'MALley, D. M., APSIT, V., PRANCE, G. T. \& BAWA, K. S. 1988. Genetics of Brazil nut (Bertholletia excelsa Humb. \& Bonpl.: Lecythidaceae). 1. Genetic variation in natural populations. Theoretical and Applied Genetics 76:923-928.

CAMARGO, P. B. D., SAlOMAO, R. P., TRUMBORE, S. \& MARTINELli, L. A. 1994. How old are large Brazil-nut trees (Bertholletia excelsa) in the Amazon? Scientia Agricola 51:389-391.

CASWELL, H. 1989. Matrix population models. Sinauer Associates, Sunderland. 328 pp.

CFV 2000. Estandares para la certificación forestal de castaña (Bertholletia excelsa). Cuarto borrador. Consejo Boliviano para la certificación Forestal Voluntaria (CFV), Santa Cruz, Bolivia. 35 pp.

CLARK, D. A. \& CLARK, D. B. 1992. Life history diversity of canopy and emergent trees in a neotropical rain forest. Ecological Monographs 62:315-344.

CLARK, D. A. \& CLARK, D. B. 1999. Assessing the growth of tropical rain forest trees: issues for forest modeling and management. Ecological Applications 9:981-997.

CLAY, J. W. 1997. Brazil nuts. The use of a keystone species for conservation and development. Pp. 246-282 in Freese C.H. (ed.). Harvesting wild species - implications for biodiversity and conservation. John Hopkins University Press, Baltimore. 
COCHRAN, M. E. \& ELLNER, S. 1992. Simple methods for calculating age-based life history parameters for stage-structured populations. Ecological Monographs 62:345-364.

CONDIT, R., HUBBELL, S. P. \& FOSTER, R. B. 1995. Mortality rates of 205 neotropical tree and shrub species and the impact of a severe drought. Ecological Monographs 65:419-439.

DE KROON, H., PLAISIER, A., VAN GROENENDAEL, J. \& CASWELL, H. 1986. Elasticity: the relative contribution of demographic parameters to population growth rate. Ecology 67:1427-1431.

DENSLOW, J. S. 1987. Tropical rainforest gaps and tree species diversity. Annual Review of Ecology and Systematics 18:431-451.

DHV 1993. Estudios agro-ecologicos, forestales y socio-economicos en la region de la castaña de la Amazonia Boliviana. Forest Resource Inventory. Banco Mundial / Gobierno de Holanda, Amersfoort. 191 pp.

DOMINGUEZ, J. 1994. Precios y costos en la produccion de castaña (Bertholletia excelsa, Hump \& Bonpl.) en Peru y Bolivia: su importancia para la conservacion del bosque tropical. Revista Forestal del Peru 21:23-38.

FEARNSIDE, P. M. 1989. Extractive reserves in Brazilian Amazonia. An opportunity to maintain forest under sustainable use. Bioscience 39:387-393.

FIFER, J. V. 1970. The empire builders: a history of the Bolivian rubber boom and the rise of the house of Suarez. Journal of Latin American Studies 2:147-173.

FORGET, P.-M. 1996. Removal of seeds of Carapa procera (Meliaceae) by rodents and their fate in rainforest in French Guiana. Journal of Tropical Ecology 12:751-761.

HAMILL, D. N. \& WRIGHT, S. J. 1986. Testing the dispersion of juveniles relative to adults: a new analytical method. Ecology 67:952-957.

HOMMA, A. K. O. 1996. Modernisation, and technological dualism in the extractive economy in Amazonia. Pp. 59-81 in Ruiz-Peres, M. \& Arnold, J. E. M. (eds). Current issues in non-timber forest products research. CIFOR, Bogor.

HOWE, H. F. \& SMALLWOOD, J. 1982. Ecology of seed dispersal. Annual Review of Ecology and Systematics $13: 201-228$.

KAINER, K. A., DURYEA, M. L., COSTA DE MACEDO, N. \& WILLIAMS, K. 1998. Brazil nut seedling establishment and autoecology in extractive reserves of Acre, Brazil. Ecological Applications 8:397-410.

KAINER, K. A., DURYEA, M. L., MATOS MALAVASI, M., RODRIGUES DA SILVA, A. \& HARRISON, J. 1999. Moist storage of Brazil nut seeds for improved germination and nursery management. Forest Ecology and Management 116:207-217.

KORNING, J. \& BALSLEV, H. 1994. Growth rates and mortality patterns of tropical lowland tree species and the relation to forest structure in Amazonian Ecuador. Journal of Tropical Ecology 10:151166.

LAFLEUR, J. R. 1992. Marketing of Brazil nuts. Food and Agricultural Organisation of the United Nations, Rome. 61 pp.

LEFKOVITCH, L. P. 1965. The study of population growth in organisms grouped by stages. Biometrics 21:1-18.

LEIGUE GÓMEZ, J. W. \& BOOT, R. G. A. In press. Producción de flores y frutos de castaña (Bertholletia excelsa) en el Nor Oeste de Bolivia. Ecología en Bolivia, in press.

LIEBERMAN, D., LIEBERMAN, M., HARTSHORN, G. \& PERALTA, R. 1985. Growth rates and age-size relationships of tropical wet forest trees in Costa Rica. Journal of Tropical Ecology 1:97-109.

LIEBERMAN, M. \& LIEBERMAN, D. 1985. Simulation of growth curves from periodic increment data. Ecology 66:632-635.

MORI, S. A. 1992. The Brazil nut industry - past, present and future. Pp. 241-251 in Plotkin, M. \& Farmocare, L. (eds). Sustainable harvest and marketing of rain forest products. Island Press, Washington, DC.

MORI, S. A. \& PRANCE, G. T. 1990. Taxonomy, ecology, and economic botany of the Brazil nut (Bertholletia excelsa Humb. \& Bonpl.: Lecythidaceae). Advances in Economic Botany 8:130-150.

MORITZ, A. 1984. Estudios biologicaos da castanha-do-Brasil (Bertholletia excelsa H.B.K.). EMRRAPA/ CPATU Documentos 29:1-82.

MOSTACEDO, B. \& FREDERICKSEN, T. S. 1999. Regeneration status of important tropical forest tree species in Bolivia: assessment and recommendations. Forest Ecology and Management 124:263-273.

MÜLLER, C. H. 1981. Castanha-do-Brasil: estudios agronomicos. EMRRAPA/CPATU Documentos 1:1-25.

MÜlleR, G. H., RODRIGUES, I. A., MÜlleR, A. A. \& MÜLlER, N. R. M. 1980. Castanha do Brazil: resultados de pesquisas. EMRRAPA/CPATU Miscelanea 2:1-25.

MURIE, J. O. 1977. Cues for cache-finding by agoutis (Dasyprocta punctata). Ecology 58:95-96.

MYERS, G. P., NEWTON, A. C. \& MELGAREJO, O. 2000. The influence of canopy gap size on natural regeneration of Brazil nut (Bertholletia excelsa) in Bolivia. Forest Ecology and Management 127:119-128.

NAGELKERKE, N. J. D. 1991. A note on a general definition of the coefficient of determination. Biometrika 78:691-692.

NELSON, B. W., ABSY, M. L., BARBOSA, E. M. \& PRANGE, G. T. 1985. Observation on flower visitors 
to Bertholletia excelsa H.B.K and Couratari tenuicarpa A.C. Sm. (Lecythidaceae). Acta Amazonica 15:225234.

OLIVEIRA, M. V. N. 2000. Artificial regeneration in gaps and skidding trails after mechanised forest exploitation in Acre, Brazil. Forest Ecology and Management 127:67-76.

O'MALlEY, D. M., BUCKLEY, D. P., PRANCE, G. T. \& BAWA, K. S. 1988. Genetics of Brazil nut (Bertholletia excelsa Humb. \& Bonpl.: Lecythidaceae) 2. Mating system. Theoretical and Applied Genetics 76:929-932.

ORTIZ, E. 1995. Survival in a nutshell. Americas 47:7-12.

PENA-CLAROS, M., BOOT, R. G. A. \& DORADO-LORA, J. In press. Enrichment planting of Bertholletia excelsa in secondary forest in the Bolivian Amazon: effect of cutting line width on survival, growth and crown traits. Forest Ecology and Management, in press.

PERES, C. A. \& BAIDER, C. 1997. Seed dispersal, spatial distribution and population structure of Brazilnut trees (Bertholletia excelsa) in southeastern Amazonia. Journal of Tropical Ecology 13:595-616.

PERES, C. A., SCHIESARI, L. C. \& DIAS-LEME, C. L. 1997. Vertebrate predation of Brazil-nuts (Bertholletia excelsa, Lecythidaceae), an agouti-dispersed Amazonian seed crop: a test of the escape hypothesis. Journal of Tropical Ecology 13:69-79.

PETERS, C. M. 1990a. Plant demography and the management of tropical forest resources: a case study of Brosimum alicastrum in Mexico. Pp. 265-272 in Gomez-Pompa, A. (ed.). Rain forest regeneration and management. Man and Biosphere, UNESCO, Paris.

PETERS, C. M. 1990b. Population ecology and management of forest fruit trees in Peruvian Amazonia. Pp. 86-98 in Anderson A. B. (ed.). Alternatives to deforestation: steps toward sustainable use of the Amazon rain forest. Columbia University Press, New York.

PETERS, C. M. 1996. Observation on the sustainable exploitation of non-timber tropical forest products. An ecologist's perspective. Pp. 19-39 in Ruiz-Peres, M. \& Arnold, J. E. M. (eds). Current issues in non-timber forest products research. CIFOR, Bogor.

PIRES, K. M. 1984. The Amazon forest. Pp. 581-602 in Sioli, H. (ed.). The Amazon. Limnology and landscape ecology of a mighty tropical river and its basin. Dr W. Junk Publishers, Dordrecht.

POORTER, L. 1999. Growth responses of 15 rain-forest tree species to a light gradient: the relative importance of morphological and physiological traits. Functional Ecology 13:396-410.

PRANCE, G. T. 1990. Fruits of the rain forest. New Scientist (13 January 1990):43-45.

RICHARDS, M. 1993. The potential of non-timber forest products in sustainable natural forest management in Amazonia. Commonwealth Forestry Review 72:21-27.

ROPELEWSKI, G. F. \& HALPERT, M. S. 1996. Quantifying Southern Oscillation-precipitation relationships. Journal of Climate 9:1043-1059.

SALOMAO, R. P. 1991. Estructura e densidade de Bertholletia excelsa H. \& B. ('Castanheira') nas regioes de Carajas, e Maraba, Estado do Para. Boletem do museu Paraense Emilio Goeldi serie botanica 7:47-68.

SILVA, J. F., RAVENTOS, J., CASWELL, H. \& TREVISAN, M. C. 1991. Population responses to fire in a tropical savanna grass, Andropogon semiberbis: a matrix model approach. Journal of Ecology 79:345-356.

SILVERTOWN, J., FRANCO, M., PISANTY, I. \& MENDOZA, A. 1993. Comparative plant demography relative importance of life-cycle components to the finite rate of increase in woody and herbaceous perennials. Journal of Ecology 81:465-476.

STOIAN, D. 2000. Shifts in forest product extraction: the post-rubber era in the Bolivian Amazon. International Tree Crops Journal 10:277-297.

TABARELLI, M. \& MANTOVANI, W. 1996. Remocao de sementes de Bertholletia excelsa (Lecythidaceae) por animais em uma floresta de terra firme na Amazonia Central, Brasil. Revista Brasilea de Biologia 56:755-760.

TERBORGH, J., LOSOS, E., RILEY, M. P. \& BOLAÑOS RILEY, M. 1993. Predation by vertebrates and invertebrates on the seeds of five canopy species of an Amazonian forest. Vegetatio 107/108:375-386.

VAN RIJSOORT, J., UGUETO, S. \& ZUIDEMA, P. 1993. The Brazil nut tree (Bertholletia excelsa): population structures in tropical rain forest and growth response of seedlings to different light intensities. M.Sc. thesis, Utrecht University, Utrecht. $68 \mathrm{pp}$.

VIANA, V. M., MELlO, R. A., MORAES, L. M. \& MENDES, N. T. 1998. Ecologia e manejo de populações de castanha-do-Pará em reservas extrativistas Xapurí, Estado do Acre. Pp. $277-292$ in Gascon C. \& Mountinho P. (eds). Floresta Amazônica: dinâmica, regeneracão e manejo. INPA, Manaus.

WATSON, W. 1901. Germination of seeds of Bertholletia excelsa. Annals of Botany 15:99-102.

WHITMORE, T. G. 1989. Canopy gaps and the two major groups of forest trees. Ecology 70:536-538.

ZAGT, R. J. 1997. Tree demography in the tropical rain forest of Guyana. Ph.D. thesis, Utrecht University, Utrecht. 251 pp.

ZEIDE, B. 1993. Analysis of growth equations. Forest Science 39:594-616.

ZUIDEMA, P. A. 2000. Demography of exploited tree species in the Bolivian Amazon. Ph.D. thesis, Utrecht University, Utrecht. $240 \mathrm{pp}$.

ZUIDEMA, P. A., DIJKMAN, W. \& VAN RIJSOORT, J. 1999. Crecimiento de plantines de Bertholletia excelsa H.B.K. en función de su tamaño y la disponibilidad de luz. Ecologia en Bolivia 22:23-36. 